$\begin{array}{ll}\text { Research Square } & \begin{array}{l}\text { Preprints are preliminary reports that have not undergone peer review. } \\ \text { They should not be considered conclusive, used to inform clinical practice, } \\ \text { or referenced by the media as validated information. }\end{array}\end{array}$

\title{
Combining Ability And Nature of Gene Effects Controlling Seed Yield And Its Component Traits In Alien Cytoplasm Based Hybrids In Sunflower (Helianthus Annuus L.)
}

Manish Sharma ( $\nabla$ manisharmagpb@sdau.edu.in )

Sardarkrushinagar Dantiwada Agricultural University https://orcid.org/0000-0002-2706-8641

Y.G.SHADAKSHARI

Director of Research, UAS

\section{Research Article}

Keywords: Sunflower, Cytosterile sources, Combining ability, gene effects

Posted Date: July 30th, 2021

DOI: https://doi.org/10.21203/rs.3.rs-693842/v1

License: () (1) This work is licensed under a Creative Commons Attribution 4.0 International License. Read Full License 


\section{Abstract}

The present research aimed to study gene effects for seed yield and its component traits in sunflower hybrids having diverse cytosterile sources from Helianthus annuus and $\mathrm{H}$. argophyllus. Five lines and ten testers were crossed in a line $\mathrm{x}$ tester mating design to develop $50 \mathrm{~F}_{1}$ hybrids for genetic analysis. The analysis of variance revealed significant differences among the traits studied. Seasonal variation was found significant for all the traits except stem diameter, volume weight and seed filling percentage. The mean squares of lines and testers from crosses both determine the GCA were also significant for most of the traits which revealed the prevalence of additive variances and additive gene action. The mean squares of lines $x$ tester interactions were also significant for all the traits considered. The significance of lines $x$ tester interactions indicated that SCA is also important in the expression of traits and demonstrated the value of non-additive variances and dominant genes controlling the various traits. Among the diverse cytosterile lines, ARG-6-3-1-4 was identified as the best general combiner for stem diameter, volume weight, seed yield, hull content, oil content and oil yield. While, the line ARG-2-1-2 was best general combiner for days to 50 per cent flowering, head diameter, 100 seed weight and seed filling percentage. The tester M17-R was observed to be best general combiner for earliness and volume weight, while RHA 93 was the best general combiner for plant height, seed yield and oil content. The best cross combinations; MUT-2-8-3-2 x GKVK 3 was found to be good specific combiner for stem diameter, 100 seed weight, seed yield, seed filling percentage, oil content and oil yield, while ARG-6-3-1-4 x GKVK 3 was good specific combiner for days to $50 \%$ flowering, plant height and 100 seed weight.

\section{Introduction}

Sunflower is an oilseed crop used for edible purpose and other industrial use. The crop is grown globally and performs well in almost all continents where it is grown. Sunflower was introduced to India during 1969 from Russia in view of its distinct advantages, viz., photo insensitivity, short duration, high seed multiplication ratio, high seed yield and better quality of oil. However, commercial cultivation of sunflower in India started during 1972 with the introduction of Russian varieties. A major event in sunflower history was the discovery of cytoplasmic male sterility (CMS) in a wild prairie sunflower, Helianthus petiolaris Nutt. (Leclercq, 1969), and subsequent identification of genes for fertility restoration by Kinman (1970); Enns et al. (1970), Leclercq (1971) and Vranceanu and Stoenescu (1971) that led to the production of commercial hybrids. Sunflower hybrids are preferred over varietal populations as hybrids offer several benefits in terms of growth, development, synchronous flowering, early maturity, higher seed setting, increased productivity, resistance to major foliar diseases and also respond to higher level of chemical fertilizer application. In India the first ever CMS based sunflower hybrid BSH-1 was released from the University of Agricultural Sciences, Bangalore (Seetharam et al. 1980) which provided the required fillip to expand sunflower cultivation in the country. Since then, many hybrids have been released for commercial cultivation by utilizing cytoplasmic genetic male sterility system. The area under sunflower in India was 0.25 million hectares with a production of 0.22 million tones and productivity of $0.9 \mathrm{t} /$ ha (Anonymous, 2019). Over $70 \%$ of the sunflower crop is being grown across the states of Karnataka, Maharashtra and Andhra Pradesh. In Karnataka it occupies an area of about 1.60 lakh ha. with a production of 1.20 lakh tonnes and productivity of $0.75 \mathrm{t} / \mathrm{ha}$. Karnataka, popularly known as the "Sunflower State" in the oilseed scenario of the country, occupies first position, accounting for $63 \%$ of the total acreage and contributing to $53 \%$ of the national sunflower production.

Much of the current germplasm used in sunflower breeding programs originated from limited genetic material, resulting in a crop with an extremely narrow genetic base. At present, only one CMS source (i.e., PET-1) is being widely used for sunflower hybrid breeding program (Seiler et al. 2017). This cytoplasmic uniformity poses a potential risk for hybrid sunflower production. Prevalence of genetic uniformity of this kind over a large area could result in genetic vulnerability of hybrids if the cytoplasm becomes susceptible to a new strain of disease or pest similar to that happened in maize when 'Texas' cytoplasm become susceptible to Helminthosporium maydis in USA (Tatum, 1971). Among several strategies available to overcome this problem, diversification of CMS source itself is possibly the cheapest and most effective method. The utilization of different cytoplasmic backgrounds in hybrid development will improve the general variability of sunflower plants and lessen the threats of epiphytotics.

Combining ability studies elucidate the nature and magnitude of gene action involved in the inheritance of character by providing the information on additive and dominance genetic variance. The estimates of general combining ability forms the basis to select parents while, specific combining ability depicts the worth of hybrids. Sunflower, being a highly cross pollinated crop is ideally suited for exploitation of heterosis. Several biometrical methods have been developed to generate information on gene action and mode of inheritance of various characters among which Line $\times$ Tester analysis (Kempthorne, 1957) is widely used method in genetic analysis in large number of crops. The GCA is the average performance of a particular inbred in a series of hybrid combinations, whereas SCA refers to the performance of a combination of specific inbred in a particular cross (Sprague and Tatum, 1942). The GCA and SCA variances provide an estimation for additive and non-additive gene actions, respectively (Falconer, 1967). In sunflower, various reports indicated the importance of both additive and non-additive genetic variances for yield and other characters (Memon et al. 2015; Riaz et al., 2017; Tyagi and Dhillon. 2017; Lakshman et al. 2019). The objectives of present research therefore were aimed at determining the potentiality of five alloplasmic female lines having cytosterility source from Helianthus annuus and Helianthus argophyllus and ten testers for developing 50 sunflower alloplasmic hybrids and to estimate the role of additive and non-additive genes so as to design breeding experiments to improve seed yield and its component traits and to expand the cytoplasmic base of sunflower hybrids.

\section{Materials And Methods}

The present investigations were undertaken at the Zonal Agricultural Research Station, Univeristy of Agricultural Sciences, Gandhi Krishi Vigyana Kendra, Bangalore, India. The research station is geographically situated at $12^{\circ} 58^{\prime} \mathrm{N}$ latitude and $77^{\circ} 35^{\prime} \mathrm{N}$ longitude at an altitude of 930 meters above mean sea level. Materials for the study consisted of five male sterile lines viz., ARG-2-1-2, MUT-2-8-3-2, E002, ARG 3 and ARG-6-3-1-4 (Fig 1-5) developed from diverse cytoplasmic male sterile sources in different nuclear genetic background (Table 1) and ten restorers/testers viz., GKVK-3, RHA 6D-1, RHA 95-C-1, LTRR 822, M17R, MR-1, RHA-272-II, X-15-NB-10, GKVK-2 and RHA-93. The list of five diversified CMS lines with their origin is furnished below.

Table 1. Diversified CMS Lines 


\begin{tabular}{|llll|}
\hline SI No & CMS designation & Cytosterility source & Nuclear Genetic background \\
\hline 1 & ARG-2-1-2 & H. argophyllus & 234 \\
2 & MUT-2-8-3-2 & H. annuus & 234 \\
\hline 3 & E002 & H. annuus & DS2 \\
\hline 4 & ARG 3 & H. argophyllus & DS2 \\
\hline 5 & ARG-6-3-1-4 & H. argophyllus & REC 428 \\
\hline
\end{tabular}

During Rabi - 2015-16, all the diverse CMS lines and 10 restorer lines were sown in the field to effect crossing in Line $\times$ Tester fashion. Staggered sowing of all inbred lines was carried out three times at an interval of two days to ensure flowering synchronization with diverse CMS lines. In order to prevent undesirable pollination, heads of CMS lines were covered with cloth bags a day prior to opening of first ray floret. Similarly, the capitula of inbred lines were also covered with cloth bags to collect pollen. Pollen from the inbred lines were collected in petri plates and applied to the flowers of female lines using camel hairbrush during morning hours. The pollination was repeated for five to six days in each of the combination to ensure sufficient seed set and simultaneously, all inbreds were sib pollinated. At maturity, the crossed seeds of 50 combinations were collected for future evaluation. Hybrids were evaluated in Kharif 2016 and Rabi/Summer 2016-17 with two replications each and experiment was laid out in randomized block design (Fig. 6). Each genotype was sown in a single row of three meter length with spacing of $60 \mathrm{~cm}$ and $30 \mathrm{~cm}$ between plants and within row respectively. All the recommended practices were followed for raising successful crop under protective irrigated condition. The data during germination till maturity were obtained from $F_{1}$ plants and their parents for days to $50 \%$ flowering, plant height $(\mathrm{cm})$, head diameter $(\mathrm{cm})$, stem diameter $(\mathrm{cm})$, days to maturity, 100 -seed weight $(\mathrm{g})$, volume weight $\left(\mathrm{g} 100 \mathrm{ml}^{-1}\right)$, seed yield $(\mathrm{kg} \mathrm{ha-1)}$, hull content (\%), seed filling percentage, oil content (\%) and oil yield (kg ha-1). The seed oil content was determined by nuclear magnetic resonance spectrometry (NMRS). The data were analyzed for determining the differences among genotypes, parents, crosses, parents vs. crosses according to Gomez and Gomez (1984), while mean squares for GCA were determined from lines and testers and specific combing ability from lines $x$ tester interactions according to statistical procedures developed by Kempthore (1957) and adopted by Singh and Choudhary (1984).

\section{Results And Discussion}

Pooled analysis of variance

Presence of genetic variability is the basic requirement for developing high yielding hybrids in sunflower breeding programme. Pooled analysis of variance for experimental design shown in table 2, indicated significant differences among genotypes, parents and crosses for all the studied traits confirming that the data is worth for genetic analysis.

The pooled analysis of variance for combining ability due to different source for twelve characters (table 3) revealed that seasonal variation was significant for all the traits except stem diameter, volume weight and seed filling percentage. The mean squares of lines and testers from crosses both determine the GCA were also significant for most of the traits which revealed the prevalence of additive variances and additive gene action. The mean squares of lines $x$ tester interactions were significant for all the traits considered. The significance of lines $x$ tester interactions indicated that SCA is also important in the expression of traits and demonstrated the value of non-additive variances and dominant genes controlling the above traits. Memon et al. (2015), Lakshman et al. (2019) and Hilli et al. (2020) also observed that both additive and non-additive genetic variations were equally important for yield and its contributing traits in sunflower.

Table 2: Pooled Analysis of variance for seed yield and its attributing traits in sunflower.

\begin{tabular}{|c|c|c|c|c|c|c|c|c|c|c|c|c|}
\hline $\begin{array}{l}\text { Source of } \\
\text { Variations }\end{array}$ & d.f & $\begin{array}{l}\text { Days to } \\
50 \% \\
\text { flowering }\end{array}$ & $\begin{array}{l}\text { Plant } \\
\text { height } \\
\text { (cm) }\end{array}$ & $\begin{array}{l}\text { Head } \\
\text { diameter } \\
(\mathrm{cm})\end{array}$ & $\begin{array}{l}\text { Stem } \\
\text { diameter } \\
\text { (cm) }\end{array}$ & $\begin{array}{l}\text { Days to } \\
\text { Maturity }\end{array}$ & $\begin{array}{l}100 \\
\text { seed } \\
\text { weight } \\
\text { (g) }\end{array}$ & $\begin{array}{l}\text { Volume } \\
\text { weight } \\
\text { (g/100ml) }\end{array}$ & $\begin{array}{l}\text { Seed yield } \\
(\mathrm{kg} / \mathrm{ha})\end{array}$ & $\begin{array}{l}\text { Hull } \\
\text { content } \\
(\%)\end{array}$ & $\begin{array}{l}\text { Seed } \\
\text { filling } \\
\text { percent }\end{array}$ & 1 \\
\hline Replicates & 1 & 0.65 & 87.08 & 2.94 & 0.05 & 3.02 & 0.05 & 2.66 & 171553.20 & 20.28 & 9.89 & \\
\hline Season & 1 & $973.11^{\star *}$ & $6509.30 * *$ & $18.72^{\star \star}$ & $0.07 * \star$ & $1024.06^{\star \star}$ & $16.18^{\star \star}$ & $17.86^{*}$ & $1000458.85^{\star \star}$ & $138.82^{\star \star}$ & 0.0002 & 4 \\
\hline Genotypes & 64 & $29.22^{\star \star}$ & $1411.20 * *$ & $7.97 * \star$ & $0.15^{\star \star}$ & $40.95^{\star \star}$ & $1.64^{\star *}$ & $27.02^{\star *}$ & $1321399.76^{\star \star *}$ & $34.35^{\star \star}$ & $37.25^{\star \star}$ & 4 \\
\hline Crosses & 49 & $22.74^{\star \star}$ & $558.12^{\star *}$ & $1.05^{\star \star}$ & $0.05^{\star \star}$ & $34.67 * *$ & $0.69 * \star$ & $29.43^{* *}$ & $147303.15^{\star \star *}$ & $30.69 * *$ & $37.99 * *$ & 2 \\
\hline Hybrids & 36 & $4.66^{\star \star}$ & $184.93^{\star *}$ & $0.84^{* \star}$ & $0.04^{\star *}$ & $12.42^{\star \star}$ & $0.48 * *$ & $6.71^{\star \star}$ & $99531.47 * *$ & $22.14^{\star *}$ & 21.65 & ; \\
\hline $\begin{array}{l}\text { Parents vs } \\
\text { Crosses }\end{array}$ & 1 & $21.34^{\star \star}$ & $25165.55^{\star \star}$ & $204.28^{\star \star}$ & 3.74 ** & 4.02 & $25.37 \star \star$ & 35.51 ** & $54769267.49 * \star$ & $316.93^{\star *}$ & $190.94^{\star *}$ & 4 \\
\hline Error & 128 & 1.08 & 47.47 & 0.21 & 0.01 & 1.70 & 0.08 & 3.29 & 36192.46 & 0.92 & 1.77 & ( \\
\hline
\end{tabular}

** Significant at $\mathrm{P} \leq 0.01$

*Significant at $\mathrm{P} \leq 0.05$

Table 3: Pooled Analysis of variance for combining ability for seed yield and its attributing traits in sunflower. 


\begin{tabular}{|c|c|c|c|c|c|c|c|c|c|c|c|}
\hline $\begin{array}{l}\text { Source of } \\
\text { Variations }\end{array}$ & d.f & $\begin{array}{l}\text { Days to } \\
50 \% \\
\text { flowering }\end{array}$ & $\begin{array}{l}\text { Plant } \\
\text { height } \\
\text { (cm) }\end{array}$ & $\begin{array}{l}\text { Head } \\
\text { diameter } \\
(\mathrm{cm})\end{array}$ & $\begin{array}{l}\text { Stem } \\
\text { diameter } \\
\text { (cm) }\end{array}$ & $\begin{array}{l}\text { Days to } \\
\text { maturity }\end{array}$ & $\begin{array}{l}100 \\
\text { seed } \\
\text { weight } \\
\text { (g) }\end{array}$ & $\begin{array}{l}\text { Volume } \\
\text { weight } \\
(\mathrm{g} / 100 \mathrm{ml}))\end{array}$ & $\begin{array}{l}\text { Seed yield } \\
\text { (kg/ha) }\end{array}$ & $\begin{array}{l}\text { Hull } \\
\text { content } \\
(\%)\end{array}$ & $\begin{array}{l}\text { Seed } \\
\text { filling } \\
\text { percent }\end{array}$ \\
\hline Replicates(R) & 1 & 1.280 & 0.551 & 1.84 & 0.03 & 1.45 & 0.048 & 10.37 & 289205.52 & $29.28 * \star$ & 28.74 \\
\hline Season(S) & 1 & $1003.52 * \star$ & $12987.88 * \star$ & $1.51^{\star \star}$ & 0.002 & $804.01 * *$ & $12.370 * \star$ & 4.14 & $9889505.58 * \star$ & $140.47^{\star * *}$ & 0.05 \\
\hline $\mathrm{R} \times \mathrm{S}$ & 1 & 0.02 & $3191.21^{\star \star}$ & $1.28 *$ & 0.002 & 1.13 & 0.094 & 53.54 ** & 48921.94 & $6.65^{\star \star}$ & 0.42 \\
\hline Crosses (C) & 49 & $22.74^{\star \star}$ & $558.12^{\star \star}$ & $1.05^{\star \star}$ & $0.05^{\star \star}$ & $34.67 * \star$ & $0.686 * \star$ & $29.43^{\star \star}$ & $147303.15^{\star \star}$ & $30.69 * \star$ & $37.99 * \star$ \\
\hline Lines (L) & 4 & $80.04^{\star \star}$ & $2723.99 \star \star$ & 1.67 & 0.03 & $111.79 * \star$ & $2.301 * \star$ & $101.65^{\star \star}$ & $341161.03 *$ & $103.75^{\star \star}$ & 131.40 ** \\
\hline Tester $(T)$ & 9 & $69.62^{\star *}$ & $1088.27 * \star$ & 1.61 & $0.10^{*}$ & $89.41^{* *}$ & 0.790 & $88.19 * \star$ & $252230.83^{*}$ & 32.48 & $61.86^{\star}$ \\
\hline $\begin{array}{l}\text { Lines X } \\
\text { Tester }\end{array}$ & 36 & $4.66^{\star \star}$ & $184.93^{\star \star}$ & $0.84 * \star$ & $0.04 * \star$ & $12.42^{\star \star}$ & $0.481^{\star \star}$ & $6.71 \star \star$ & $99531.47^{\star \star}$ & 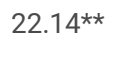 & $21.65^{\star \star}$ \\
\hline$S \times C$ & 49 & $2.64^{\star}$ & $132.63^{\star \star}$ & $0.42^{\star \star}$ & 0.003 & $5.64 * \star$ & 0.043 & 1.42 & 24376.23 & 1.14 & 1.31 \\
\hline$S \times L$ & 4 & 3.66 & 124.19 & 0.29 & 0.002 & 1.22 & 0.02 & $11.84^{\star \star}$ & 40277.69 & 0.23 & 1.45 \\
\hline $\mathrm{S} \times \mathrm{T}$ & 9 & $4.63^{\star}$ & 168.23 & 0.68 & 0.001 & 9.03 & 0.07 & 0.51 & 42703.38* & 1.01 & 0.85 \\
\hline$S X L x T$ & 36 & $2.03^{\star}$ & $124.67 * \star$ & $0.37 *$ & 0.001 & $5.28 * \star$ & 0.03 & 0.48 & 18027.61 & 1.27 & 1.40 \\
\hline Error & 98 & 1.15 & 41.21 & 0.20 & 0.007 & 2.04 & 0.083 & 3.21 & 44015.29 & 0.88 & 1.32 \\
\hline
\end{tabular}

** Significant at $\mathrm{P} \leq 0.01$

*Significant at $\mathrm{P} \leq 0.05$

Table 4: Estimates of general combining ability effects of lines for seed yield and its attributes in sunflower

\begin{tabular}{|c|c|c|c|c|c|c|c|c|c|c|c|c|}
\hline Lines & $\begin{array}{l}\text { Days to } \\
50 \% \text { flow } \\
\text { ering }\end{array}$ & $\begin{array}{l}\text { Plant } \\
\text { height } \\
\text { (cm) }\end{array}$ & $\begin{array}{l}\text { Head } \\
\text { diameter } \\
\text { (cm) }\end{array}$ & $\begin{array}{l}\text { Stem } \\
\text { diameter } \\
\text { (cm) }\end{array}$ & $\begin{array}{l}\text { Days to } \\
\text { maturity }\end{array}$ & $\begin{array}{l}100 \\
\text { seed } \\
\text { weight } \\
\text { (g) }\end{array}$ & $\begin{array}{l}\text { Volume } \\
\text { weight } \\
\text { (g/100ml) }\end{array}$ & $\begin{array}{l}\text { Seed } \\
\text { yield } \\
\text { (Kg/ha) }\end{array}$ & $\begin{array}{l}\text { Hull } \\
\text { content } \\
(\%)\end{array}$ & $\begin{array}{l}\text { Seed } \\
\text { filling } \\
\text { percent }\end{array}$ & $\begin{array}{l}\text { Oil } \\
\text { content } \\
(\%)\end{array}$ & $\begin{array}{c}\text { Oil yield } \\
\text { (Kg/ha) }\end{array}$ \\
\hline $\begin{array}{l}\text { ARG- } \\
2-1-2\end{array}$ & -1.670 ** & $4.088^{\star \star}$ & 0.270 ** & 0.0001 & 2.580 ** & 0.363 ** & 0.473 & $\underset{* \star}{93.574}$ & $\begin{array}{l}-0.969 \\
\star *\end{array}$ & 1.686 ** & $\underset{\star \star}{2.571}$ & $\begin{array}{l}83.189 \\
\star \star\end{array}$ \\
\hline $\begin{array}{l}\text { MUT- } \\
2-8-3- \\
2\end{array}$ & 0.155 & $4.430 * \star$ & -0.075 & -0.005 & 0.670 ** & 0.046 & 1.019 ** & -60.981 & -0.190 & 0.523 ** & $\begin{array}{l}-3.967 \\
\star *\end{array}$ & $\begin{array}{l}-98.022 \\
\star \star\end{array}$ \\
\hline E002 & $-0.995^{\star \star}$ & $-5.713^{\star \star}$ & -0.035 & -0.008 & $-0.630 * *$ & -0.211 ** & $-1.869 * \star$ & -50.603 & $\begin{array}{l}1.465 \\
* *\end{array}$ & 0.377 * & $\begin{array}{l}0.444 \\
\star *\end{array}$ & -12.490 \\
\hline ARG 3 & $0.530 * \star$ & $-11.390 * *$ & $-0.272^{\star \star}$ & -0.029 * & 0.795 ** & -0.225 ** & -1.446 ** & $\begin{array}{l}-88.253 \\
\star \star\end{array}$ & $\underset{* \star}{1.745}$ & -3.101 ** & -2.688 & $\begin{array}{l}-83.452 \\
\star \star\end{array}$ \\
\hline $\begin{array}{l}\text { ARG- } \\
6-3-1- \\
4\end{array}$ & $1.980 * \star$ & $8.585^{\star \star}$ & 0.113 & 0.041 ** & 1.745 ** & 0.027 & 1.822 ** & $\begin{array}{l}106.263 \\
\star \star\end{array}$ & -2.051 & 0.515 ** & $\begin{array}{l}3.640 \\
\star \star\end{array}$ & ${ }_{\star \star}^{110.775}$ \\
\hline SE \pm & 0.170 & 1.015 & 0.071 & 0.013 & 0.226 & 0.046 & 0.283 & 33.172 & 0.148 & 0.182 & 0.065 & 11.268 \\
\hline
\end{tabular}

** Significant at $\mathrm{P} \leq 0.01$

*Significant at $\mathrm{P} \leq 0.05$

Table 5: Estimates of general combining ability effects of testers for seed yield and its component traits in sunflower. 


\begin{tabular}{|c|c|c|c|c|c|c|c|c|c|c|c|c|}
\hline Testers & $\begin{array}{l}\text { Days to } \\
50 \% \\
\text { flowering }\end{array}$ & $\begin{array}{l}\text { Plant } \\
\text { height } \\
\text { (cm) }\end{array}$ & $\begin{array}{l}\text { Head } \\
\text { diameter } \\
\text { (cm) }\end{array}$ & $\begin{array}{l}\text { Stem } \\
\text { diameter } \\
\text { (cm) }\end{array}$ & $\begin{array}{l}\text { Days to } \\
\text { maturity }\end{array}$ & $\begin{array}{l}100 \\
\text { seed } \\
\text { weight } \\
\text { (g) }\end{array}$ & $\begin{array}{l}\text { Volume } \\
\text { weight } \\
\text { (g/100ml) }\end{array}$ & $\begin{array}{l}\text { Seed } \\
\text { yield } \\
\text { (Kg/ha) }\end{array}$ & $\begin{array}{l}\text { Hull } \\
\text { content } \\
(\%)\end{array}$ & $\begin{array}{l}\text { Seed } \\
\text { filling } \\
\text { percent }\end{array}$ & $\begin{array}{l}\text { Oil } \\
\text { content } \\
(\%)\end{array}$ & $\begin{array}{l}\text { Oil yield } \\
(\mathrm{Kg} / \mathrm{ha})\end{array}$ \\
\hline $\begin{array}{l}\text { GKVK- } \\
3\end{array}$ & $3.480 * *$ & -1.608 & -0.100 & 0.042 * & 3.695 ** & 0.232 & $2.071 * \star$ & 88.047 & -0.088 & 1.654 ** & $\begin{array}{l}-0.605 \\
\star \star\end{array}$ & 13.298 \\
\hline $\begin{array}{l}\text { RHA- } \\
6 \mathrm{D}-1\end{array}$ & 0.880 ** & 1.233 & 0.135 & -0.003 & 1.845 ** & -0.080 & 0.245 & -89.587 & $\begin{array}{l}-1.053 \\
\star \star\end{array}$ & 1.047 ** & $\begin{array}{l}0.870 \\
\star \star\end{array}$ & -11.862 \\
\hline $\begin{array}{l}\text { RHA- } \\
95-\mathrm{C}-1\end{array}$ & $1.730^{\star * *}$ & $13.943^{\star \star}$ & $0.545^{\star *}$ & 0.106 ** & $2.095 * *$ & $\underset{* \star}{0.184}$ & 0.703 & 72.991 & -0.261 & 1.277 ** & $\underset{\star \star}{0.942}$ & $\underset{* \star}{44.960}$ \\
\hline $\begin{array}{l}\text { LTRR- } \\
822\end{array}$ & 1.730 ** & $5.662^{\star \star}$ & 0.055 & 0.054 ** & 1.145 ** & 0.021 & -3.152 ** & 13.824 & $\begin{array}{l}-2.018 \\
\star *\end{array}$ & -0.755 & 0.088 & 8.946 \\
\hline M17-R & $-2.120^{\star \star}$ & $-3.093^{\star \star}$ & $-0.410 * \star$ & -0.074 ** & -2.805 ** & $\begin{array}{l}-0.440 \\
\star \star\end{array}$ & 3.166 ** & $\begin{array}{l}-133.831 \\
\star \star\end{array}$ & $\begin{array}{l}-0.646 \\
\star \star\end{array}$ & $\begin{array}{l}-0.732 \\
\star \star\end{array}$ & 0.210 * & $\begin{array}{l}-42.453 \\
\star \star\end{array}$ \\
\hline MR-1 & $-1.270 * *$ & 0.663 & 0.125 & 0.052 ** & -0.855 ** & -0.117 & 0.145 & $\begin{array}{l}105.547 \\
\star\end{array}$ & 0.367 & 1.182 ** & $\begin{array}{l}0.279 \\
\star \star\end{array}$ & $\begin{array}{l}41.580 \\
*\end{array}$ \\
\hline $\begin{array}{l}\text { RHA- } \\
272-I I\end{array}$ & -1.470 ** & -1.077 & $0.235^{\star}$ & -0.002 & -1.955 ** & $\underset{* \star}{0.198}$ & -0.505 & $\begin{array}{l}-159.909 \\
\star \star\end{array}$ & 2.121 & $\begin{array}{l}-3.848 \\
\star \star\end{array}$ & $\begin{array}{l}-1.152 \\
\star \star\end{array}$ & $\begin{array}{l}-77.819 \\
\star \star\end{array}$ \\
\hline $\begin{array}{l}X-15- \\
\text { NB-10 }\end{array}$ & -0.070 & 0.093 & -0.070 & 0.028 & -0.105 & -0.092 & -3.161 ** & -75.009 & 1.113 & 1.187 ** & 0.201 * & -24.241 \\
\hline $\begin{array}{l}\text { GKVK- } \\
2\end{array}$ & -1.520 ** & -0.068 & $-0.355^{\star \star}$ & -0.116 ** & -1.955 ** & 0.023 & 1.745 ** & -0.842 & 1.451 & $\begin{array}{l}-1.760 \\
\star \star\end{array}$ & ${ }_{* \star}^{0.281}$ & 6.896 \\
\hline $\begin{array}{l}\text { RHA- } \\
93\end{array}$ & -1.370 ** & -15.748 & -0.160 & -0.086 ** & -1.105 ** & 0.073 & -1.256 ** & $\underset{* *}{178.769}$ & -0.984 & 0.748 ** & ${ }_{\star \star}^{1.115}$ & $\begin{array}{l}40.695 \\
*\end{array}$ \\
\hline SE \pm & 0.240 & 1.435 & 0.101 & 0.019 & 0.319 & 0.064 & 0.401 & 46.912 & 0.210 & 0.257 & 0.092 & 15.936 \\
\hline
\end{tabular}

** Significant at $\leq 0.01$

* Significant at $\leq 0.05$

General combining ability effects

Combining ability of a line/strain to produce superior progenies upon hybridization with other lines/strains is an important criteria to select parents for developing superior new hybrids. To reduce the crop growth period, lesser number of days to flowering and maturity is preferred. The sunflower growers require short duration hybrids, because such hybrids reduce the incidence of insect-pest, disease attack and adverse environmental effects (Memon et al. 2015). For days to $50 \%$ flowering and days to maturity only line E002 exhibited significant negative gca effect (table 4) for both these traits while among testers highest significant negative gca effect was recorded by M17-R (table 5) for both the traits followed by GKVK 2 and RHA-272-II. Thus the lines E002 and testers M17-R, GKVK 2 and RHA-272-II were found to be good general combiners for earliness. Therefore, these lines could be used in the synthesis of early maturing hybrids. Meena et al. (2013) and Azad et al. (2016) have also identified good general combiners for early flowering.

As reduced plant height promotes resistant to lodging, there is also a huge interest in the development of semi-dwarf hybrids. The most prominent negative effect of the GCA for plant height was found in the CMS lines in ARG 3 (-11.390) and for the same traits among the testers in RHA-93 (-15.748), hence, the lines and testers with negative gca effects can be used in hybridization programme to synthesize medium stature plants. For head diameter, line ARG-2-1-2 (0.270) exhibited significant positive gca effects while line ARG 3 (-0.272) exihibited significant negative gca effect while among testers, only RHA-95-C-1 (0.545) and RHA 272-II (0.235) exhibited significant positive gca effect. Riaz et al. (2017) have also reported similar results and inferred that these identified lines and testers with positive gca effect could be used in further breeding programme to synthesis hybrids with large head size thus intern contributing to increased yield. For stem diameter lines ARG-6-3-1-4 (0.041) exhibited highest significant positive effect and ARG 3 (-0.029) exhibited significant negative gca effect. Testers RHA-95-C-1 (0.106) followed by MR-1 (0.052) exhibited highest significant positive gca effect as also observed in the studies of Lakshman et al. (2019) indicating the preponderance of additive effect in the inheritance of this character.

The seed weight of a genotype serves as an indicator to the expression of an end product i.e., seed yield as it is an important character contributing to seed yield. Lines ARG-2-1-2 (0.363) exhibited highest significant positive gca effect while testers viz., GKVK 3 (0.232), RHA 272-II (0.198) and RHA-95-C-1 (0.184) registered significant positive gca effect indicating their high utility in the breeding programme. For volume weight lines ARG-6-3-1-4 (1.822) and MUT-2-8-3-2 (1.019) exhibited significant positive gca effect. Three testers expressed significant positive gca effect, highest being manifested by M17-R (3.166) followed by GKVK 3 (2.071) and GKVK-2 (1.745). Hence, these lines and testers showing positive gca effects could be used in hybridization programme to develop hybrids with high seed weight and volume weight. Patil et al. (2012) have also reported good general combiners for these yield attributing traits.

The gca effects for seed yield varied both in magnitude and direction among both lines and testers. Lines ARG-6-3-1-4 (106.263) and ARG-2-1-2 (93.574) expressed significant positive gca effects while, ARG 3 (-88.253) exhibited significant negative gca effect. Among testers gca effects ranged from 178.769 (RHA 93) to -159.909 (RHA 272-II). Only one tester recorded positive gca effect and two recorded negative gca effects. It was interesting to note that the line ARG-6-3-1-4 is good general combiners for most of the yield contributing characters, showing that a positive association exists between seed yield and its attributes such as plant height, stem diameter, head diameter and volume weight. Hence, ARG-6-3-1-4 could also be used in breeding for development of 
hybrids with higher seed yield. In earlier reports, Salem and Ali (2012), Memon et al. (2015) and Chahal et al. (2019) have also reported good general combiners for seed yield. Patil et al. (2012) in their study observed significant gca effects for hull content. In our results also lines ARG-6-3-1-4 (-2.051) and ARG-2-1-2 (-0.969) exhibited significant negative gca effect which is desirable. Four of the ten testers registered significant negative gca effect, highest being recorded by LTRR 822 (-2.018) followed by RHA 6D-1 (-1.053) and M17-R (-0.646). Parents showing negative gca for this trait can be considered to develop hybrids having low hull content. For seed filling percentage lines ARG-2-1-2 (1.686), MUT-2-8-3-2 (0.523), ARG-6-3-1-4 (0.515) and E002 (0.377) exhibited significant positive gca. whereas, line ARG 3 (-3.101) exhibited significant negative gca effect. All the testers, recorded significant gca effect, with six being positive and four being negative. Highest positive being recorded by GKVK 3 (1.654) followed by RHA-95-C-1 (1.277). Lakshman et al. (2019) have reported similar results for seed filling percentage inferring that the lines and tester having positive significant gca effects appeared to transmit the increasing alleles with additive effects.

As Sunflower is an oilseed crop, oil is the ultimate end product and hence, increase in oil content is of prime most important. All the lines tested expressed significant $g c a$ effects of which three of them were positive and two of them were negative. The line ARG-6-3-1-4 (3.640) manifested the highest positive significant gca effect followed by ARG-2-1-2 (2.571) and E002 (0.444). Seven testers registered significant positive gca effect. The testers RHA-93 (1.115) followed by RHA 95-C-1 (0.942) and RHA 6D-1 (0.870) were the best general combiners for oil yield. Similar findings for oil content were reported by Azad et al. (2016) and Attia et al. (2020). Oil yield is a derivative trait of oil content and seed yield. Good general combiners for this trait have been identified in earlier works of Lakshman et al. (2019) and Hilli et al. (2020). In the present study except ARG 3, all lines exhibited significant gca effect, highest significant positive gca effect is being manifested by ARG-6-3-1-4 (110.775) followed by ARG-2-1-2 (83.189). Among the testers, highest significant positive gca being manifested by RHA-95-C-1 (44.960) followed by MR-1 (41.580) and RHA-93 (40.695). On the contrary, highest negative gca effect registered by RHA 272-II (-77.819) followed by M17-R (-42.453). Kaya and Atakisi (2004) reported that superior hybrids were obtained by crossing CMS females and restorer males with high GCA and SCA effects. On the similar lines, ARG-6-3-1-4 and ARG-2-1-2 and testers RHA-95-C-1, MR-1 and RHA-93 with high positive GCA estimates can be desirable parents to be used for developing sunflower hybrids with improved oil yield.

Specific combining ability effects

The relative performance of any cross combination is expressed as specific combining ability and is denoted in terms of sca effects and SCA variance. The SCA variance denotes non additive or dominance portion of variance and generally non fixable on selfing but can be exploited in hybrid combination. Out of 50 crosses, only 5 hybrids recorded the desirable significant negative sca effects and 3 hybrids exhibited significant positive sca effects for days to $50 \%$ flowering (Table 6). The crosses which exhibited highest significant negative sca effects for earliness are MUT-2-8-3-2 x M-17-R (-1.805) followed by ARG-6-3-14 x GKVK-3 (-1.730) and ARG-2-1-2 x GKVK-2 (-1.580). The parents of best specific combinations, MUT-2-8-3-2 x M-17-R (Table 7) were of low x low general combiners indicating the involvement of non-additive gene action and over dominance in the expression of this trait. With respect to days to maturity, 17 out of 50 crosses manifested significant sca effects, of which the highest negative sca effect was manifested by ARG $3 \times$ GKVK-2 (-2.545), followed by ARG $3 \times$ LTRR-822 (-2.395) and ARG-2-1-2 x RHA 6D-1 (-2.220). Ghaffari et al. (2020) also obtained similar results and concluded that crosses showing negative significant sca effects possess dominant or over dominant type of genes with decreasing effect hence may be exploited for earliness in sunflower.

For plant height, best crosses which exhibited high negative sca effect were ARG-6-3-1-4 x GKVK-3 (-15.125) followed by ARG-6-3-1-4 x RHA 6D-1 (-12.465) and ARG 3 x GKVK-2 (-10.265). Bhoite et al. (2018) also reported good specific combiners for plant height. Head diameter in case of sunflower is an important yield attributing character since there is a positive correlation of head size with number of seeds per head and in turn with seed yield. The hybrid MUT-2-8-3-2 $x$ GKVK-3 (1.160) topped the list of crosses which showed highest significant positive sca effects followed by ARG-6-3-1-4 x GKVK-2 (0.728) and ARG-6-3-1-4 x MR-1 (0.648). Preponderence of non-additive gene action for this trait was also observed by Parameshwarappa et al. (2008) and Machikowa et al. (2011). Ten out of 50 hybrids showed significant sca effect for stem diameter, of which five were in positive and five were in negative direction. The hybrid ARG-6-3-1-4 $x$ GKVK-2 (0.246) expressed significant positive sca effect followed by MUT-2-8-3-2 x GKVK-3 (0.141) and ARG $3 \times$ RHA 6D-1 (0.138). Contrary to this, cross ARG 3 x GKVK-2 (-0.254) exhibited highest significant negative sca effects followed by ARG-6-3-1-4 x RHA-6D-1 (-0.227). However, the magnitude of sca effects among the hybrids was very low for this trait. These results are in confirmation with those observed in the studies of Shankar et al. (2007).

Eight cross combinations showed significant positive sca effects for 100 seed weight. Of these, ARG-2-1-2 x RHA 6D-1 (0.535), ARG-6-3-1-4 x GKVK-3 (0.525) and MUT-2-8-3-2 x X-15-NB-10 (0.456) were the best specific combiners. Of the top three ranked hybrid for the trait two crosses involved at least one parent with low gca effect i.e., these crosses were of high $x$ low or low $x$ high type of specific combinations suggesting the involvement of non-additive gene action in the inheritance of this trait. Patil et al. (2017) reported good specific combiners for 100 seed weight and also reported existence of non additive gene action in the inheritance of this trait. The cross combination E002 x X-15-NB-10 (2.816) was the best specific combiner for volume weight followed by MUT-2-8-3-2 $\mathrm{x}$ MR-1 (2.157) and MUT-2-8-3-2 x LTRR-822 (2.049). All the three best crosses involved at least one parent with low gca effects, clearly suggesting the involvement of non-additive gene action in the inheritance of the trait. Similar results were obtained by Chandra et al. (2011) and Lakshman et al. (2019).

With respect to seed yield, sca ranged from - 258.81 to 404.04 with the best specific combiner being MUT-2-8-3-2 x GKVK-3 (404.036), followed by ARG-2-1-2 x LTRR-822 (295.926) and E002 x M-17-R (254.425). A large reservoir of variability was evident as could be inferred from the range as well as magnitude and direction of sca effects for this character. In the first two top crosses viz., MUT-2-8-3-2 x GKVK-3 and ARG-2-1-2 x LTRR-822, at least one parent with high and other parent with low gca effects were present. This could be attributed to the involvement of non-additive gene action. However, it was interesting to note that in the third cross viz., E002 x M-17-R both the parents with low gca effects were involved suggesting preponderence of over dominance and epitasis. Dhillon and Tyagi (2016) also reported good specific combiners for seed yield in sunflower.

Thirty five out of 50 crosses showed significant sca effects for hull content, of which ARG-2-1-2 x RHA-93 (-4.646) topped the list of hybrids expressing significant negative sca effect followed by ARG-6-3-1-4 x M-17-R (-3.588) and ARG-2-1-2 x X-15-NB-10 (-3.501). In contrary, cross MUT-2-8-3-2 x X-15-NB-10

(3.731) and ARG-6-3-1-4 x GKVK 3 (3.648) exhibited highest significant negative sca effects. Bhoite et al. (2018) reported desired negative specific combiners

Page 6/19 
for this trait. With respect to seed filling percentage, fourteen and thirteen crosses exhibited significant positive and negative sca effects, respectively. The cross, MUT-2-8-3-2 x RHA 272-II (5.329), ARG-2-1-2 x LTRR-822 (3.556) and ARG-2-1-2 x X-15-NB-10 (2.718) were the best specific combiners for seed filling percentage. Meena et al. (2013) and Sharma and Shadakshari (2021) also reported good specific combiners for seed filling percentage.

Highly significant sca effects for oil content were observed in thirty nine crosses, of which nineteen and twenty crosses expressed positive and negative significant sca effects, respectively. The hybrids E002 x X-15-NB-10 (2.520), MUT-2-8-3-2 x GKVK-3 (2.070) and ARG-2-1-2 x RHA-93 (1.961) topped the list of crosses expressing significant positive sca effects. The best specific combination E002 $\times$ X-15-NB-10 was having parents with low combining ability which indicated the involvement of non-additive gene action and also existence of over dominance and epitasis in the inheritance of this trait. With reference to oil yield, hybrids viz., MUT-2-8-3-2 x GKVK-3 (171.895) followed by ARG-2-1-2 x LTRR-822 (98.581) and MUT-2-8-3-2 x RHA-93 (72.726) were the best specific combiners among 50 hybrids. Top ranking hybrids had atleast one parent with low combining ability type of parental combinations suggesting the action of non additive gene in the inheritance of this trait. Non additive gene action for oil content and oil yield was also reported by Azad et al. (2016) and Hilli et al. (2020). None of the hybrids were good specific combiners for all the characters studied. However, the cross combination MUT-2-8-3-2 x GKVK 3 was found to be good specific combiner for stem diameter, 100 seed weight, seed yield, seed filling percentage, oil content and oil yield hence it can be tested in large scale yield trials over locations and seasons to confirm its potentiality for commercial cultivation. As these hybrids are based on diverse cytosterile sources, even their on par performance with PET 1 cytoplasm based hybrids will be sufficient enough so that the cytoplasmic base of sunflower hybrids can be expanded.

Variance due to general and specific combining ability effects

The ratio of GCA to SCA is used to indicate the predominance of non-additive gene action in the inheritance of the traits. The results revealed that, among the twelve characters studied, characters viz., days to $50 \%$ flowering, plant height, days to maturity and volume weight there was preponderance of additive gene action as indicated by greater than unity GCA to SCA ratio (Table 8), while remaining characters viz., head diameter, stem diameter, 100 seed weight, seed yield, hull content, seed filling percent, oil content and oil yield manifested a higher magnitude of SCA variance as compared to GCA variance. Similar to the present findings, non-additive gene actions were documented for head diameter (cm), stem diameter (cm), 100 seed weight ( $\mathrm{g})$, seed yield ( $\mathrm{kg} / \mathrm{ha})$, hull content (\%), seed filling percent, oil content (\%), and oil yield (kg/ha) by Bhoite et al. (2018) and Hilli et al. (2020).

Proportional contribution of lines, testers and line $\mathrm{x}$ tester interaction for the performance of hybrids

The data on the proportional contribution of lines, testers and line $\mathrm{x}$ tester interaction for twelve quantative traits revealed that the line $\mathrm{x}$ tester interaction contributed more for the performance of hybrids for most of the characters such head diameter, stem diameter, 100 seed weight, seed yield, hull content, seed filling percent, oil content and oil yield (Table 9). However, for days to $50 \%$ flowering, days to maturity and volume weight contribution of the testers was more when compared to lines and line $x$ tester interaction. Shankar et al. (2007) observed similar results and emphasized that due care needs to be excised while selecting the inbreds/lines to be used as parents for hybridization and to safely use these sources to broaden the genetic base of CMS source so that this valuable oilseed crop can be safeguarded from any eventuality of biotic and abiotic threats in future.

Table 6: Estimates of specific combing ability effects of crosses for seed yield and its attributing traits sunflower. 


\begin{tabular}{|c|c|c|c|c|c|c|c|c|c|c|c|c|}
\hline Hybrids & $\begin{array}{l}\text { Days to } \\
50 \% \\
\text { flowering }\end{array}$ & $\begin{array}{l}\text { Plant } \\
\text { height } \\
\text { (cm) }\end{array}$ & $\begin{array}{l}\text { Head } \\
\text { diameter } \\
(\mathrm{cm})\end{array}$ & $\begin{array}{l}\text { Stem } \\
\text { diameter } \\
\text { (cm) }\end{array}$ & $\begin{array}{l}\text { Days to } \\
\text { maturity }\end{array}$ & $\begin{array}{l}100 \\
\text { seed } \\
\text { weight } \\
\text { (g) }\end{array}$ & $\begin{array}{l}\text { Volume } \\
\text { weight } \\
\text { (g/100ml) }\end{array}$ & $\begin{array}{l}\text { Seed } \\
\text { yield } \\
(\mathrm{Kg} / \mathrm{ha})\end{array}$ & $\begin{array}{l}\text { Hull } \\
\text { content } \\
(\%)\end{array}$ & $\begin{array}{l}\text { Seed } \\
\text { filling } \\
\text { percent }\end{array}$ & $\begin{array}{l}\text { Oil } \\
\text { content } \\
(\%)\end{array}$ & $\begin{array}{l}\text { Oil yield } \\
\text { (Kg/ha) }\end{array}$ \\
\hline $\begin{array}{l}\text { ARG-2- } \\
1-2 x \\
\text { GKVK-3 }\end{array}$ & -0.330 & 0.048 & -0.335 & -0.019 & -0.570 & -0.119 & -0.020 & $\begin{array}{l}-244.963 \\
*\end{array}$ & 0.491 & -2.268 & $\begin{array}{l}-1.104 \\
* *\end{array}$ & $-104.931 * *$ \\
\hline $\begin{array}{l}\text { ARG-2- } \\
1-2 x \\
\text { RHA 6D- } \\
1\end{array}$ & -0.230 & -0.793 & 0.530 * & 0.109 * & -2.220 & 0.535 ** & 0.589 & 6.281 & 0.928 & -0.087 & $\begin{array}{l}0.681 \\
\star \star\end{array}$ & 11.969 \\
\hline $\begin{array}{l}\text { ARG-2- } \\
1-2 \times 95- \\
\text { C-1 }\end{array}$ & -0.330 & -0.002 & -0.030 & -0.040 & $\begin{array}{l}-1.970 \\
\star \star\end{array}$ & 0.413 ** & -0.377 & 62.870 & -0.784 & 1.233 * & $\begin{array}{l}-1.073 \\
\star \star\end{array}$ & 6.120 \\
\hline $\begin{array}{l}\text { ARG-2- } \\
1-2 x \\
\text { LTRR- } \\
822\end{array}$ & -0.080 & -3.123 & 0.060 & 0.011 & 0.980 & 0.217 & 1.416 & $\underset{\star \star}{295.926}$ & -2.097 & $\begin{array}{l}3.556 \\
* *\end{array}$ & $\begin{array}{l}-0.457 \\
\star\end{array}$ & 98.581 ** \\
\hline $\begin{array}{l}\text { ARG-2- } \\
1-2 \times M- \\
17-R\end{array}$ & 1.770 ** & ${ }_{\star \star}^{-10.118}$ & -0.475 * & 0.010 & 0.930 & -0.220 & -0.305 & -180.030 & ${ }_{* *}^{1.424}$ & 1.058 & $\underbrace{0.771}_{* \star}$ & -57.825 \\
\hline $\begin{array}{l}\text { ARG-2- } \\
1-2 x \\
\text { MR-1 }\end{array}$ & 0.420 & 3.178 & -0.060 & 0.051 & 0.230 & -0.350 * & 0.741 & -145.797 & 0.924 & -2.747 & 1.047 & -30.002 \\
\hline $\begin{array}{l}\text { ARG-2- } \\
1-2 x \\
\text { RHA } \\
272-I I\end{array}$ & 0.620 & -0.283 & 0.080 & -0.015 & 2.580 ** & 0.074 & -0.504 & 136.325 & 1.335 & 0.863 & $\begin{array}{l}-1.429 \\
\star \star\end{array}$ & 16.296 \\
\hline $\begin{array}{l}\text { ARG-2- } \\
1-2 \times X- \\
15-N B- \\
10\end{array}$ & 0.470 & 7.347 * & -0.165 & -0.012 & 1.480 * & $\begin{array}{l}-0.633 \\
\star \star\end{array}$ & -1.746 & -98.575 & 1.393 * & $\begin{array}{l}-2.081 \\
\star *\end{array}$ & 0.155 & -34.101 \\
\hline $\begin{array}{l}\text { ARG-2- } \\
1-2 \times \\
\text { GKVK-2 }\end{array}$ & -1.580 ** & 5.183 & 0.220 & -0.073 & -0.670 & -0.038 & 0.771 & 99.481 & 1.030 * & $\begin{array}{l}-1.739 \\
\star \star\end{array}$ & $\begin{array}{l}-0.550 \\
\star \star\end{array}$ & 23.351 \\
\hline $\begin{array}{l}\text { ARG-2- } \\
1-2 x \\
\text { RHA-93 }\end{array}$ & -0.730 & -1.438 & 0.175 & -0.018 & -0.770 & 0.122 & -0.563 & 68.481 & $\begin{array}{l}-4.646 \\
\star \star\end{array}$ & 2.213 & ${ }_{* *}^{1.961}$ & 70.540 \\
\hline $\begin{array}{l}\text { MUT-2- } \\
\text { 8-3-2 x } \\
\text { GKVK-3 }\end{array}$ & -0.405 & 1.830 & 1.160 ** & 0.141 ** & -0.820 & 0.395 ** & 0.626 & $\begin{array}{l}404.036 \\
\star \star\end{array}$ & -2.191 & ${ }_{\star \star}^{1.932}$ & $\underbrace{2.070}_{\star \star}$ & 171.895 ** \\
\hline $\begin{array}{l}\text { MUT-2- } \\
8-3-2 x \\
\text { RHA 6D- } \\
1\end{array}$ & 0.945 & 3.665 & -0.025 & -0.056 & 0.530 & $\begin{array}{l}-0.453 \\
\star \star\end{array}$ & 0.427 & -205.830 & $\underbrace{1.754}_{* *}$ & $\begin{array}{l}-1.804 \\
\star *\end{array}$ & $\begin{array}{l}-1.771 \\
\star *\end{array}$ & $-94.955 * *$ \\
\hline $\begin{array}{l}\text { MUT-2- } \\
8-3-2 x \\
95-C-1\end{array}$ & -0.905 & -1.970 & -0.585 * & 0.015 & -1.220 & 0.268 & -0.376 & -0.352 & 0.0001 & -2.994 & 0.285 & -0.152 \\
\hline $\begin{array}{l}\text { MUT-2- } \\
8-3-2 x \\
\text { LTRR- } \\
822\end{array}$ & -0.905 & -0.765 & -0.045 & -0.031 & -2.020 & -0.041 & 2.049 * & -130.075 & $\begin{array}{l}-1.973 \\
\star \star\end{array}$ & 0.704 & $\begin{array}{l}-1.271 \\
\star *\end{array}$ & -67.103 \\
\hline $\begin{array}{l}\text { MUT-2- } \\
8-3-2 x \\
\text { M-17-R }\end{array}$ & -1.805 ** & $\begin{array}{l}-7.210 \\
\star\end{array}$ & -0.405 & -0.070 & -0.570 & $\begin{array}{l}-0.565 \\
\star \star\end{array}$ & -1.094 & $\begin{array}{l}-258.808 \\
*\end{array}$ & -2.120 & $\begin{array}{l}-4.747 \\
\star \star\end{array}$ & -0.128 & -77.874 * \\
\hline $\begin{array}{l}\text { MUT-2- } \\
8-3-2 x \\
\text { MR-1 }\end{array}$ & -0.155 & $\begin{array}{l}-8.965 \\
\star \star\end{array}$ & -0.390 & -0.032 & 0.230 & -0.076 & 2.157 * & 65.703 & -0.023 & 0.746 & $\begin{array}{l}-0.562 \\
* *\end{array}$ & 3.896 \\
\hline $\begin{array}{l}\text { MUT-2- } \\
8-3-2 x \\
\text { RHA } \\
272-11\end{array}$ & 0.545 & 5.175 & -0.200 & 0.017 & 0.580 & 0.241 & 0.637 & 65.881 & $\begin{array}{l}3.398 \\
* *\end{array}$ & $\underset{* \star}{5.329}$ & 0.312 & 34.445 \\
\hline $\begin{array}{l}\text { MUT-2- } \\
8-3-2 x \\
\text { X-15- } \\
\text { NB-10 }\end{array}$ & -0.355 & -4.945 & 0.380 & -0.082 & -0.520 & 0.456 ** & -1.847 * & 99.037 & $\begin{array}{l}3.731 \\
\star *\end{array}$ & -1.058 & $\begin{array}{l}-0.732 \\
\star \star\end{array}$ & 20.172 \\
\hline $\begin{array}{l}\text { MUT-2- } \\
8-3-2 \text { X } \\
\text { GKVK-2 }\end{array}$ & 3.095 ** & 7.265 * & -0.135 & 0.027 & 2.830 ** & $\begin{array}{l}-0.463 \\
\star *\end{array}$ & -1.723 & $\underset{*}{-225.130}$ & $\begin{array}{l}-3.062 \\
\star \star\end{array}$ & 0.714 & $\begin{array}{l}0.579 \\
\star \star\end{array}$ & -63.050 \\
\hline
\end{tabular}




\begin{tabular}{|c|c|c|c|c|c|c|c|c|c|c|c|c|}
\hline Hybrids & $\begin{array}{l}\text { Days to } \\
50 \% \\
\text { flowering }\end{array}$ & $\begin{array}{l}\text { Plant } \\
\text { height } \\
\text { (cm) }\end{array}$ & $\begin{array}{l}\text { Head } \\
\text { diameter } \\
\text { (cm) }\end{array}$ & $\begin{array}{l}\text { Stem } \\
\text { diameter } \\
\text { (cm) }\end{array}$ & $\begin{array}{l}\text { Days to } \\
\text { maturity }\end{array}$ & $\begin{array}{l}100 \\
\text { seed } \\
\text { weight } \\
\text { (g) }\end{array}$ & $\begin{array}{l}\text { Volume } \\
\text { weight } \\
\text { (g/100ml) }\end{array}$ & $\begin{array}{l}\text { Seed } \\
\text { yield } \\
\text { (Kg/ha) }\end{array}$ & $\begin{array}{l}\text { Hull } \\
\text { content } \\
(\%)\end{array}$ & $\begin{array}{l}\text { Seed } \\
\text { filling } \\
\text { percent }\end{array}$ & $\begin{array}{l}\text { Oil } \\
\text { content } \\
\text { (\%) }\end{array}$ & $\begin{array}{l}\text { Oil yield } \\
\text { (Kg/ha) }\end{array}$ \\
\hline & & 5.920 & 0.245 & 0.072 & & & -0.857 & 185.537 & 0.485 & & $\underset{\star \star \star}{1.217}$ & 72.726 * \\
\hline $\begin{array}{l}\text { MUT-2- } \\
8-3-2 x \\
\text { RHA-93 }\end{array}$ & -0.055 & & & & 0.980 & 0.236 & & & & 1.176 * & & \\
\hline $\begin{array}{l}\text { E002 X } \\
\text { GKVK-3 }\end{array}$ & 0.745 & 10.748 & 0.070 & 0.031 & 0.230 & -0.212 & -0.485 & -135.508 & $\begin{array}{l}-1.006 \\
\star\end{array}$ & $\begin{array}{l}-1.744 \\
\star \star\end{array}$ & 0.631 & -28.960 \\
\hline $\begin{array}{l}\text { E002 x } \\
\text { RHA 6D- } \\
1\end{array}$ & -0.905 & 5.708 & -0.240 & 0.037 & -1.670 * & -0.065 & -1.437 & 3.403 & -0.401 & 1.428 * & 0.326 & 4.908 \\
\hline $\begin{array}{l}\text { E002 x } \\
95-C-1\end{array}$ & -0.255 & 1.447 & 0.200 & 0.048 & -0.170 & -0.020 & 0.328 & 14.270 & $\begin{array}{l}1.410 \\
\star *\end{array}$ & 0.575 & -2.151 & -37.474 \\
\hline $\begin{array}{l}\text { E002 x } \\
\text { LTRR- } \\
822\end{array}$ & 0.495 & -0.372 & 0.065 & 0.019 & 2.280 ** & -0.089 & -2.098 * & -72.397 & 0.062 & -2.250 & $\begin{array}{l}1.218 \\
\star \star\end{array}$ & -4.715 \\
\hline $\begin{array}{l}\text { E002 x } \\
M-17-R\end{array}$ & -0.405 & 1.658 & 0.305 & -0.125 ** & -1.520 * & 0.300 * & 1.825 * & 254.425 & 1.818 & 1.370 * & $\begin{array}{l}-1.579 \\
\star \star\end{array}$ & 57.106 \\
\hline $\begin{array}{l}\text { EO02 x } \\
\text { MR-1 }\end{array}$ & 0.495 & -4.298 & -0.030 & -0.039 & 0.530 & 0.312 * & -1.912 * & -9.952 & 0.327 & -0.035 & $\begin{array}{l}-0.465 \\
\star\end{array}$ & -11.184 \\
\hline $\begin{array}{l}\text { EOO2 x } \\
\text { RHA } \\
272-I I\end{array}$ & -1.055 & -5.383 & -0.190 & -0.135 ** & -0.870 & -0.019 & 0.278 & 40.225 & $\begin{array}{l}-1.262 \\
\star \star\end{array}$ & $\begin{array}{l}-4.392 \\
* \star\end{array}$ & $\begin{array}{l}1.276 \\
\star *\end{array}$ & 38.730 \\
\hline $\begin{array}{l}\text { E002 x } \\
\text { X-15- } \\
\text { NB-10 }\end{array}$ & -0.205 & -1.753 & 0.015 & 0.076 & -0.220 & -0.101 & 2.816 ** & -26.619 & $\begin{array}{l}-2.401 \\
* *\end{array}$ & 2.718 & 2.520 & 38.415 \\
\hline $\begin{array}{l}\text { E002 } x \\
\text { GKVK-2 }\end{array}$ & 0.745 & -5.293 & -0.075 & 0.055 & 1.130 & 0.264 & -0.072 & 76.992 & 0.173 & 2.438 & -0.072 & 25.695 \\
\hline $\begin{array}{l}\text { E002 } x \\
\text { RHA-93 }\end{array}$ & 0.345 & -2.463 & -0.120 & 0.035 & 0.280 & -0.371 * & 0.759 & -144.841 & 1.280 & -0.110 & $\begin{array}{l}-1.704 \\
\star \star\end{array}$ & -82.519 * \\
\hline $\begin{array}{l}\text { ARG } 3 x \\
\text { GKVK-3 }\end{array}$ & 1.720 ** & 2.500 & 0.358 & 0.035 & 2.555 ** & $\begin{array}{l}-0.589 \\
\star \star\end{array}$ & -1.159 & 104.920 & $\begin{array}{l}-0.943 \\
*\end{array}$ & ${ }_{* \star}^{1.901}$ & 0.080 & 36.993 \\
\hline $\begin{array}{l}\text { ARG } 3 x \\
\text { RHA 6D- } \\
1\end{array}$ & 0.320 & 3.885 & 0.348 & 0.138 ** & $\begin{array}{l}4.405 \\
* * *\end{array}$ & 0.098 & -0.583 & 126.998 & 1.142 * & 1.403 * & $\begin{array}{l}-0.433 \\
*\end{array}$ & 32.683 \\
\hline $\begin{array}{l}\text { ARG } 3 x \\
95-C-1\end{array}$ & 0.470 & $\begin{array}{l}-6.375 \\
*\end{array}$ & 0.262 & -0.021 & 1.155 & -0.231 & 0.289 & -74.469 & 1.998 & 1.120 & 1.176 & -5.127 \\
\hline $\begin{array}{l}\text { ARG } 3 x \\
\text { LTRR- } \\
822\end{array}$ & 0.470 & -0.820 & -0.147 & -0.050 & -2.395 & -0.103 & -1.127 & -28.635 & 2.177 & 0.400 & $\begin{array}{l}-0.600 \\
\star \star\end{array}$ & -22.813 \\
\hline $\begin{array}{l}\text { ARG } 3 x \\
M-17-R\end{array}$ & -0.180 & 4.985 & 0.442 & 0.136 * & -0.445 & 0.228 & 0.246 & 104.909 & 2.466 & ${ }_{\star \star}^{1.710}$ & $\underbrace{1.052}_{\star \star}$ & 56.169 \\
\hline $\begin{array}{l}\text { ARG } 3 x \\
\text { MR-1 }\end{array}$ & -1.280 * & -0.420 & -0.167 & -0.038 & $\begin{array}{l}-1.895 \\
\star *\end{array}$ & -0.095 & -0.604 & -9.802 & $\begin{array}{l}-1.647 \\
\star \star\end{array}$ & -0.480 & -0.056 & -6.531 \\
\hline $\begin{array}{l}\text { ARG } 3 x \\
\text { RHA } \\
272-I I\end{array}$ & -0.830 & 3.345 & -0.027 & 0.061 & -1.545 * & -0.095 & 0.041 & -87.402 & $\begin{array}{l}-2.341 \\
* *\end{array}$ & -2.137 & 1.047 & -4.180 \\
\hline $\begin{array}{l}\text { ARG } 3 x \\
\text { X-15- } \\
\text { NB-10 }\end{array}$ & 0.020 & 1.300 & -0.223 & 0.002 & 0.355 & 0.220 & 1.932 * & -13.969 & $\begin{array}{l}-3.501 \\
\star \star\end{array}$ & -0.019 & -0.361 & -7.055 \\
\hline $\begin{array}{l}\text { ARG } 3 x \\
\text { GKVK-2 }\end{array}$ & -1.530 ** & $\begin{array}{l}-10.265 \\
\star \star\end{array}$ & -0.738 ** & -0.254 ** & -2.545 & 0.210 & 0.391 & -4.802 & 0.394 & -1.052 & $\underset{* \star}{0.622}$ & 8.440 \\
\hline $\begin{array}{l}\text { ARG } 3 x \\
\text { RHA-93 }\end{array}$ & 0.820 & 1.865 & -0.107 & -0.009 & 0.355 & 0.355 * & 0.572 & -117.747 & 0.256 & -2.848 & $\begin{array}{l}-2.528 \\
* \star\end{array}$ & -88.579 * \\
\hline $\begin{array}{l}\text { ARG-6- } \\
3-1-4 x \\
\text { GKVK-3 }\end{array}$ & -1.730 ** & $\begin{array}{l}-15.125 \\
\star \star\end{array}$ & -1.253 ** & -0.187 * & -1.395 & 0.525 ** & 1.038 & -128.486 & $\begin{array}{l}3.648 \\
\star *\end{array}$ & 0.178 & $\begin{array}{l}-1.678 \\
\star \star\end{array}$ & -74.997 * \\
\hline
\end{tabular}




\begin{tabular}{|c|c|c|c|c|c|c|c|c|c|c|c|c|}
\hline Hybrids & $\begin{array}{l}\text { Days to } \\
50 \% \\
\text { flowering }\end{array}$ & $\begin{array}{l}\text { Plant } \\
\text { height } \\
\text { (cm) }\end{array}$ & $\begin{array}{l}\text { Head } \\
\text { diameter } \\
\text { (cm) }\end{array}$ & $\begin{array}{l}\text { Stem } \\
\text { diameter } \\
\text { (cm) }\end{array}$ & $\begin{array}{l}\text { Days to } \\
\text { maturity }\end{array}$ & $\begin{array}{l}100 \\
\text { seed } \\
\text { weight } \\
\text { (g) }\end{array}$ & $\begin{array}{l}\text { Volume } \\
\text { weight } \\
\text { (g/100ml) }\end{array}$ & $\begin{array}{l}\text { Seed } \\
\text { yield } \\
(\mathrm{Kg} / \mathrm{ha})\end{array}$ & $\begin{array}{l}\text { Hull } \\
\text { content } \\
(\%)\end{array}$ & $\begin{array}{l}\text { Seed } \\
\text { filling } \\
\text { percent }\end{array}$ & $\begin{array}{l}\text { Oil } \\
\text { content } \\
(\%)\end{array}$ & $\begin{array}{l}\text { Oil yield } \\
(\mathrm{Kg} / \mathrm{ha})\end{array}$ \\
\hline $\begin{array}{l}\text { ARG-6- } \\
3-1-4 \times \\
\text { RHA 6D- } \\
1\end{array}$ & -0.130 & $\begin{array}{l}-12.465 \\
\star \star\end{array}$ & -0.613 ** & $-0.227 * \star$ & -1.045 & -0.116 & 1.004 & 69.148 & $\begin{array}{l}-3.424 \\
\star \star\end{array}$ & -0.941 & ${ }_{* *}^{1.197}$ & 45.395 \\
\hline $\begin{array}{l}\text { ARG-6- } \\
3-1-4 x \\
95-C-1\end{array}$ & 1.020 & 6.900 * & 0.153 & 0.001 & 2.205 ** & -0.430 ** & 0.136 & -2.319 & -2.624 & 0.064 & $\begin{array}{l}1.763 \\
\star \star\end{array}$ & 36.633 \\
\hline $\begin{array}{l}\text { ARG-6- } \\
3-1-4 x \\
\text { LTRR- } \\
822\end{array}$ & 0.020 & 5.080 & 0.068 & 0.051 & 1.155 & 0.016 & -0.240 & -64.819 & $\underbrace{1.831}_{\star \star}$ & $\begin{array}{l}-2.411 \\
\star \star\end{array}$ & $\begin{array}{l}1.109 \\
\star *\end{array}$ & -3.950 \\
\hline $\begin{array}{l}\text { ARG-6- } \\
3-1-4 x \\
M-17-R\end{array}$ & 0.620 & 10.685 & 0.132 & 0.049 & 1.605 * & 0.257 & -0.672 & 79.504 & $\begin{array}{l}-3.588 \\
\star *\end{array}$ & 0.609 & -0.116 & 22.424 \\
\hline $\begin{array}{l}\text { ARG-6- } \\
3-1-4 x \\
\text { MR-1 }\end{array}$ & 0.520 & 10.505 & 0.648 ** & 0.058 & 0.905 & 0.209 & -0.382 & 99.847 & 0.419 & ${ }_{\star *}^{2.514}$ & 0.036 & 43.821 \\
\hline $\begin{array}{l}\text { ARG-6- } \\
3-1-4 x \\
\text { RHA } \\
272-11\end{array}$ & 0.720 & -2.855 & 0.338 & 0.072 & -0.745 & -0.202 & -0.452 & -155.030 & $\begin{array}{l}-1.130 \\
*\end{array}$ & 0.337 & $\begin{array}{l}-1.206 \\
\star \star\end{array}$ & -85.290 * \\
\hline $\begin{array}{l}\text { ARG-6- } \\
3-1-4 x \\
\text { X-15- } \\
\text { NB-10 }\end{array}$ & 0.070 & -1.950 & -0.008 & 0.017 & -1.095 & 0.058 & -1.156 & 40.126 & 0.778 & 0.440 & $\begin{array}{l}-1.582 \\
\star \star\end{array}$ & -17.430 \\
\hline $\begin{array}{l}\text { ARG-6- } \\
3-1-4 x \\
\text { GKVK-2 }\end{array}$ & -0.730 & 3.110 & 0.728 ** & 0.246 ** & -0.745 & 0.026 & 0.633 & 53.459 & $\underbrace{1.465}_{* \star}$ & -0.361 & $\begin{array}{l}-0.579 \\
\star \star\end{array}$ & 5.565 \\
\hline $\begin{array}{l}\text { ARG-6- } \\
3-1-4 x \\
\text { RHA-93 }\end{array}$ & -0.380 & -3.885 & -0.193 & -0.079 & -0.845 & -0.342 * & 0.089 & 8.570 & ${\underset{\star \star}{* \star}}^{2.624}$ & -0.431 & $\underbrace{1.054}_{\star \star}$ & 27.831 \\
\hline SE \pm & 0.536 & 3.210 & 0.226 & 0.042 & 0.714 & 0.144 & 0.896 & 104.899 & 0.470 & 0.575 & 0.205 & 35.633 \\
\hline
\end{tabular}

** significant at $\mathrm{P} \leq 0.01$ * significant at $\mathrm{P} \leq 0.05$

Table 7: Top ranking hybrids with high sca effects in desirable direction for seed yield and its component traits in sunflower. 


\begin{tabular}{|c|c|c|c|}
\hline Rank & Days to $50 \%$ flowering & Rank & Plant height (cm) \\
\hline 1 & MUT-2-8-3-2 x M-17-R & 1 & ARG-6-3-1-4 x GKVK-3 \\
\hline 2 & ARG-6-3-1-4 x GKVK-3 & 2 & ARG-6-3-1-4 x RHA 6D-1 \\
\hline 3 & ARG-2-1-2 x GKVK-2 & 3 & ARG 3 x GKVK-2 \\
\hline 4 & ARG 3 x GKVK-2 & 4 & ARG-2-1-2 x M-17-R \\
\hline 5 & ARG $3 \times$ MR-1 & 5 & MUT-2-8-3-2 x MR-1 \\
\hline Rank & Head diameter (cm) & Rank & Stem diameter (cm) \\
\hline 1 & MUT-2-8-3-2 x GKVK-3 & 1 & ARG-6-3-1-4 x GKVK-2 \\
\hline 2 & ARG-6-3-1-4 x GKVK-2 & 2 & MUT-2-8-3-2 x GKVK-3 \\
\hline 3 & ARG-6-3-1-4 x MR-1 & 3 & ARG 3 x RHA 6D-1 \\
\hline 4 & ARG-2-1-2 x RHA 6D-1 & 4 & ARG $3 \times \mathrm{M}-17-\mathrm{R}$ \\
\hline 5 & ARG $3 \times \mathrm{M}-17-\mathrm{R}$ & 5 & ARG-2-1-2 x RHA 6D-1 \\
\hline Rank & Days to maturity & Rank & 100 seed weight $(\mathrm{g})$ \\
\hline 1 & ARG 3 x GKVK-2 & 1 & ARG-2-1-2 x RHA 6D-1 \\
\hline 2 & ARG 3 x LTRR-822 & 2 & ARG-6-3-1-4 x GKVK-3 \\
\hline 3 & ARG-2-1-2 x RHA 6D-1 & 3 & MUT-2-8-3-2 x X-15-NB-10 \\
\hline 4 & MUT-2-8-3-2 x LTRR-822 & 4 & ARG-2-1-2 x 95-C-1 \\
\hline 5 & ARG-2-1-2 x 95-C-1 & 5 & MUT-2-8-3-2 x GKVK-3 \\
\hline Rank & Volume weight (g/100ml) & Rank & Seed yield(kg/ha) \\
\hline 1 & E002 x X-15-NB-10 & 1 & MUT-2-8-3-2 x GKVK-3 \\
\hline 2 & MUT-2-8-3-2 x MR-1 & 2 & ARG-2-1-2 x LTRR-822 \\
\hline 3 & MUT-2-8-3-2 x LTRR-822 & 3 & E002 $\times$ M-17-R \\
\hline 4 & ARG $3 \times$ X-15-NB-10 & 4 & MUT-2-8-3-2 x RHA-93 \\
\hline 5 & E002 x M-17-R & 5 & ARG-2-1-2 x RHA 272-II \\
\hline Rank & Hull content (\%) & Rank & Seed filling per-cent \\
\hline 1 & ARG-2-1-2 x RHA-93 & 1 & MUT-2-8-3-2 x RHA 272-II \\
\hline 2 & ARG-6-3-1-4 x M-17-R & 2 & ARG-2-1-2 x LTRR-822 \\
\hline 3 & ARG-2-1-2 x X-15-NB-10 & 3 & ARG-2-1-2 x X-15-NB-10 \\
\hline 4 & ARG-6-3-1-4 x RHA 6D-1 & 4 & ARG-6-3-1-4 x MR-1 \\
\hline 5 & MUT-2-8-3-2 x GKVK-2 & 5 & E002 x GKVK-2 \\
\hline Rank & Oil content (\%) & Rank & Oil yield (kg/ha) \\
\hline 1 & E002 x X-15-NB-10 & 1 & MUT-2-8-3-2 x GKVK-3 \\
\hline 2 & MUT-2-8-3-2 x GKVK-3 & 2 & ARG-2-1-2 x LTRR-822 \\
\hline 3 & ARG-2-1-2 x RHA-93 & 3 & MUT-2-8-3-2 x RHA-93 \\
\hline 4 & ARG-6-3-1-4 x 95-C-1 & 4 & ARG-2-1-2 x RHA-93 \\
\hline 5 & E002 x RHA 272-II & 5 & E002 $\times$ M-17-R \\
\hline
\end{tabular}

Table 8: Variance due to general and specific combining ability effects for seed yield and its attributing traits in sunflower. 


\begin{tabular}{|llll|}
\hline Characters & Variance due to GCA & Variance due to SCA & GCA SCA \\
\hline Days to $50 \%$ flowering & 2.456 & 0.877 & 2.800 \\
\hline Plant height $(\mathrm{cm})$ & 62.160 & 35.930 & 1.730 \\
\hline Head diameter $(\mathrm{cm})$ & 0.048 & 0.158 & 0.304 \\
\hline Stem diameter $(\mathrm{cm})$ & 0.002 & 0.009 & 0.222 \\
\hline Days to maturity & 3.285 & 2.594 & 1.266 \\
\hline 100 seed weight $(\mathrm{g})$ & 0.049 & 0.100 & 0.490 \\
\hline volume weight $(\mathrm{g} / 100 \mathrm{ml})$ & 3.057 & 0.875 & 3.494 \\
\hline Seed yield $(\mathrm{kg} / \mathrm{ha})$ & 8422.689 & 13879.046 & 0.607 \\
\hline Hull content $(\%)$ & 2.241 & 5.314 & 0.422 \\
\hline Seed filling $(\%)$ & 3.177 & 5.083 & 0.625 \\
\hline Oil content $(\%)$ & 1.850 & 7.344 & 0.252 \\
\hline Oil yield $(\mathrm{kg} / \mathrm{ha})$ & 2681.516 & 6346.924 & 0.422 \\
\hline
\end{tabular}

Table 9: Proportional contribution of lines, testers and $L x T$ interaction to the total variance among the hybrids.

\section{Declarations}

\begin{tabular}{lllll} 
Sl. No. & Characters & Lines $(\mathrm{L})$ & Testers $(\mathrm{T})$ & $\mathbf{L} \mathbf{x}$ T interaction \\
\hline 1 & Days to $50 \%$ flowering & 28.730 & 56.228 & 15.042 \\
\hline 2 & Plant height $(\mathrm{cm})$ & 39.842 & 35.814 & 24.344 \\
\hline 3 & Head diameter $(\mathrm{cm})$ & 13.012 & 28.252 & 58.736 \\
\hline 4 & Stem diameter (cm) & 3.950 & 35.319 & 60.732 \\
\hline 5 & Days to maturity & 26.322 & 47.364 & 26.314 \\
\hline 6 & 100 seed weight (g) & 27.379 & 21.159 & 51.462 \\
\hline 7 & volume weight (g/100ml) & 28.199 & 55.045 & 16.756 \\
\hline 8 & Seed yield (kg/ha) & 18.907 & 31.451 & 49.643 \\
\hline 10 & Hull content (\%) & 27.589 & 19.434 & 52.977 \\
\hline 11 & Seed filling (\%) & 28.229 & 29.903 & 41.868 \\
\hline 12 & Oil content $(\%)$ & 4.622 & 13.035 & 82.344 \\
\hline
\end{tabular}

Funding (Not applicable)

Conflicts of interest/Competing interests (Authors Declare that there is no conflict of interest)

Availability of data and material (Not applicable)

Code availability (Not applicable)

\section{References}

1. Anonymous (2019) http://www.fao.org/faostat

2. Azad K, Shabbir G, Ayub KM, Mahmmod T, Hussain SZ, Alghabari F, Daur I (2016) Combining ability analysis and gene action studies of different quantitative traits in sunflower by line $x$ tester. Crop Res 51:1-4

3. Bhoite KD, Dubey RB, Vyas M, Mundra SL, Ameta KD (2018) Evaluation of combining ability and heterosis for seed yield in breeding lines of sunflower (Helianthus annuus L.) using line $x$ tester analysis. J Pharmacognosy Phytochemistry 7:1457-1464

4. Chahal RK, Dhillon SK, Kandhola SS, Kaur G, Kaila V, Tyagi V (2019) Magnitude and nature of gene effects controlling oil content and quality components in sunflower (Helianthus annuus L.). Helia 42:73-84

5. Chandra BS, Kumar SS, Ranganadha ARG, Dudhe MY (2011) Combining ability studies for development of new hybrids over environments in sunflower (Helianthus annuus L.). J Agric Sci 3:123-128

6. Dhillon SK, Tyagi V (2016) Combining ability studies for development of new sunflower hybrids based on diverse cytoplasmic sources. Helia $39: 71$

7. Enns H, Dorrell DG, Hoes JA, Chubb WO (1970) Sunflower research-A progress report. Proc. 4th Inter Sunflower Conf 162-168 
8. Falconer SP (1967) Introduction to quantitative genetics. The Ronald Press Company, New York

9. Ghaffari M, Shariati F, Fard NS (2020) Heterosis Expression for Agronomic Features of Sunflower. J Agric Food 1:1-10

10. Hilli HJ, Shobhaimmadi CS, Hilli J, Bankapur NS (2020) Combining ability studies and the gene action involved in sunflower lines. Int J Curr Microbiol App Sci 9:2206-2215

11. Kaya Y, Atakisi I (2004) Combining ability analysis of some yield characters of sunflower (Helianthus annuus L.). Helia 47:75-84

12. Kempthorne $O$ (1957) An Introduction to genetic statistics. John Willey and Sons, Inc., New York

13. Kinman ML (1970) New developments in USDA and state experiment station sunflower breeding programmes. Proc 4th Inter Sunflower Conf Memphis Tennessee U.S.A

14. Lakshman SS, Chakrabarty NR, Kole PC (2019) Study on the combining ability and gene action in sunflower through line $x$ tester matting design. Electronic J Plant Breed 10:816-826

15. Leclercq P (1969) Line sterile cytoplasmique chezk tournesol. Ann Amelior Planta 12:99-106

16. Leclercq P (1971) La sterile male cytoplasmique du turnesol-1,premieres etudes sur la restauration de law fertile. Annales del' Ameloration des Plantes 21:45-54

17. Machikowa T, Saetang C, Funpeng K (2011) General and specific combining ability for quantitative characters in sunflower. J Agric Sci 3:91

18. Memon S, Baloch MJ, Baloch GM, Jatoi WA (2015) Combining ability through linex tester analysis for phenological, seed yield, and oil traits in sunflower (Helianthus annuus L.). Euphytica 204:199-209

19. Meena CR, Meena HP, Sinha B (2013) Fertility restoration, combining ability effects and heterosis in sunflower (Helianthus annuus L.) using different CMS sources. J Oilseeds Res 30:60-64

20. Parameshwarappa KG, Ram J, Lingaraju BS (2008) Heterosis and combining ability for seed yield, oil content and other agronomic traits involving mutant restorer lines in sunflower (Helianthus annuus L.). J Oilseeds Res 25:8-12

21. Patil R, Goud I, Kulkarni V, Banakar C (2012) Combining ability and gene action studies for seed yield and its components in sunflower (Helianthus annuus L.). Electronic J Plant Breed 3:861-867

22. Riaz A, Tahir MHN, Rizwan M, Nazir MF, Riaz B (2017) Combining ability analysis for achene yield and related components in sunflower (Helianthus annuus L.). Helia 40:177

23. Salem AH, Ali MA (2012) Combining ability for sunflower yield contributing characters and oil content over different water supply environments. J American Sci 8:227-233

24. Seetharam A, Giriraj K, Kusumakumari P (1980) Phenotypic stability of seed yield in sunflower hybrids. Indian J Genet 40:102-104

25. Seiler GJ, Lili LQ, Marek LF (2017) Utilization of sunflower crop wild relatives for cultivated sunflower improvement. Crop Sci 57:1083-1101

26. Shankar VG, Ganesh M, Ranganatha ARG, Suman A, Sridhar V (2007) Combining ability studies in diverse CMS sources in sunflower (Helianthus annuus L.). Indian J Agric Res 41:64-67

27. Sharma M, Shadakshari YG (2021) Combining ability and nature of gene effects controlling seed yield and its component traits in Sunflower (Helianthus annuus L.). Multilogic Sci 10:1717-1720

28. Sprague GF, Tatum LA (1942) General and specific combining ability in single crosses of corn. J American Soc Agron 34:923-932

29. Tatum LA (1971) Southern corn leaf blight epidemic. Science 171:1113-1116

30. Tyagi V, Dhillon SK (2017) Effect of alien cytoplasm on combining ability for earliness and seed yield in sunflower under irrigation and drought stress. Helia

31. Vranceanu AV, Stoenescu FM (1971) Pollen fertility restorer gene from cultivated sunflower. Euphytica 20:536-541

\section{Figures}



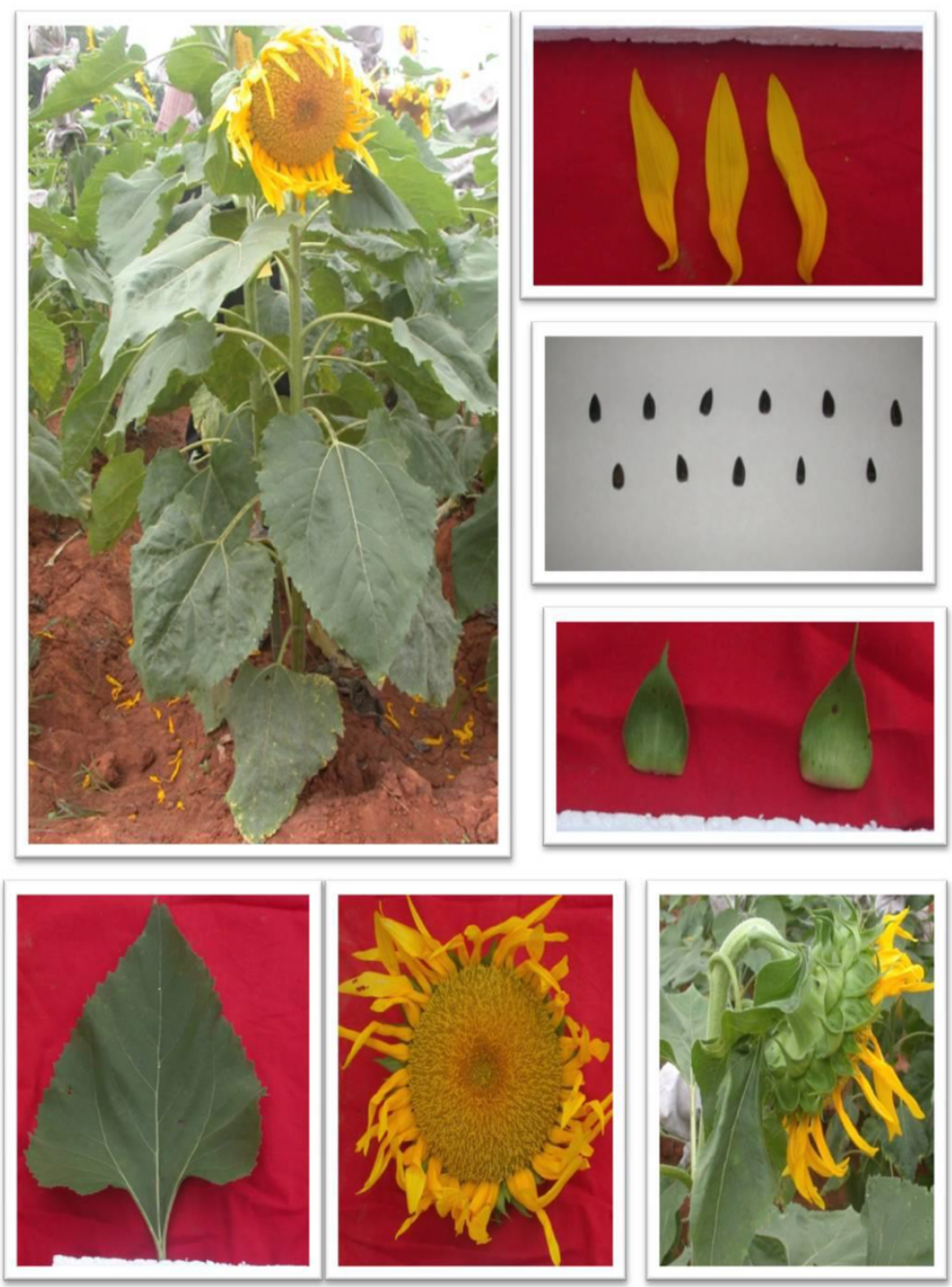

Figure 1

Diversified CMS line E002 


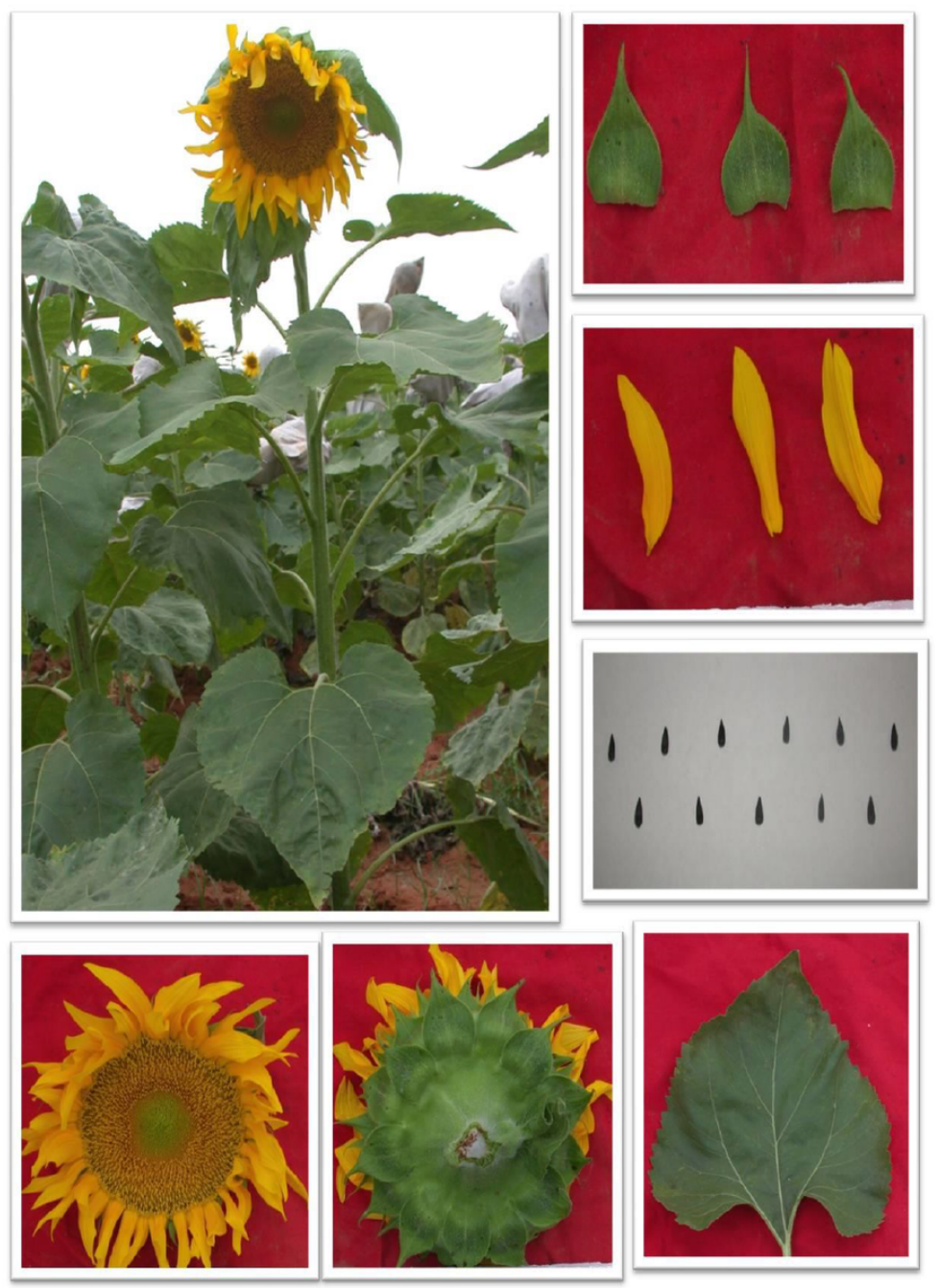

Figure 2

Diversified CMS line ARG-3 

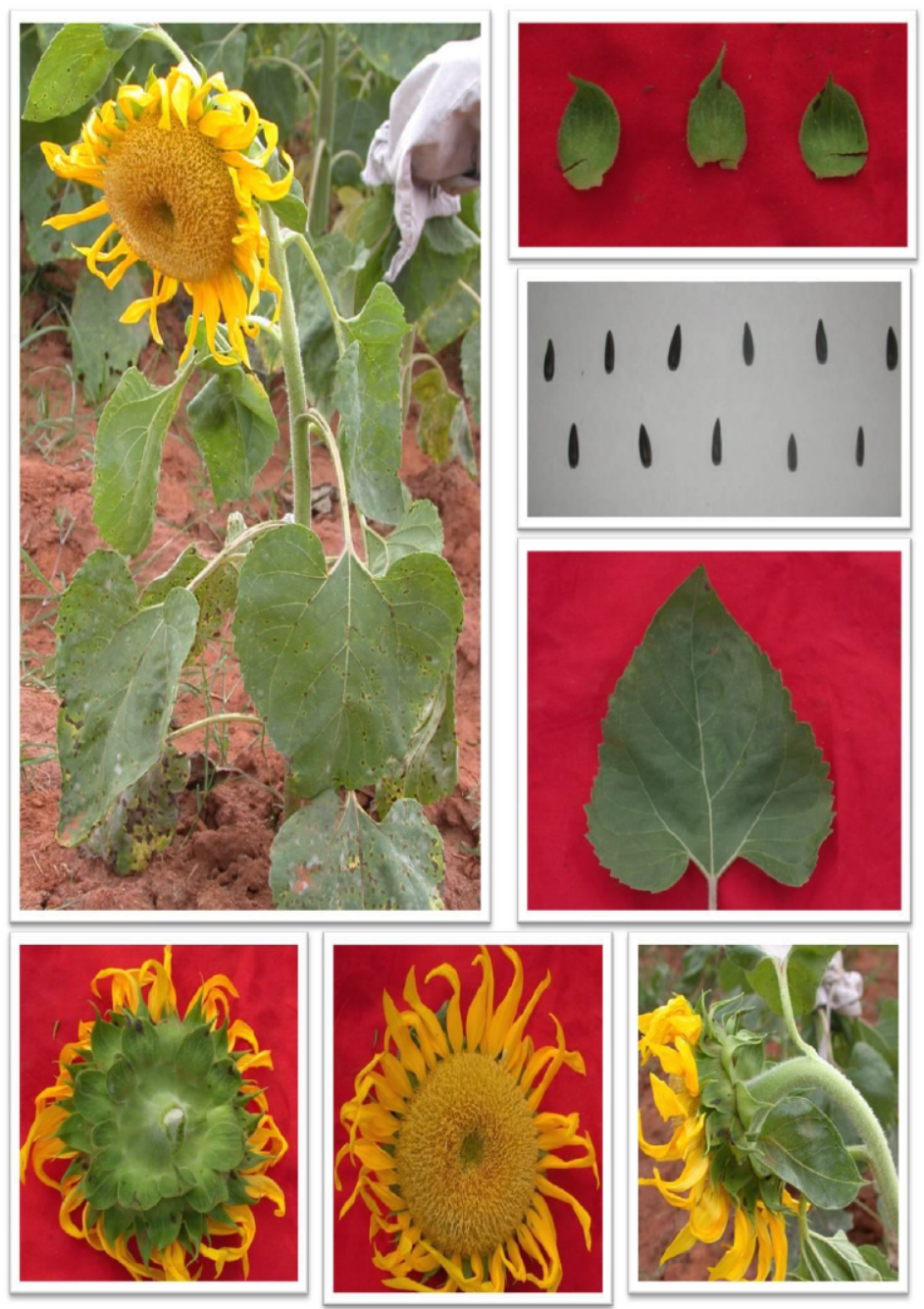

Figure 3

Diversified CMS line ARG 2-1-2 


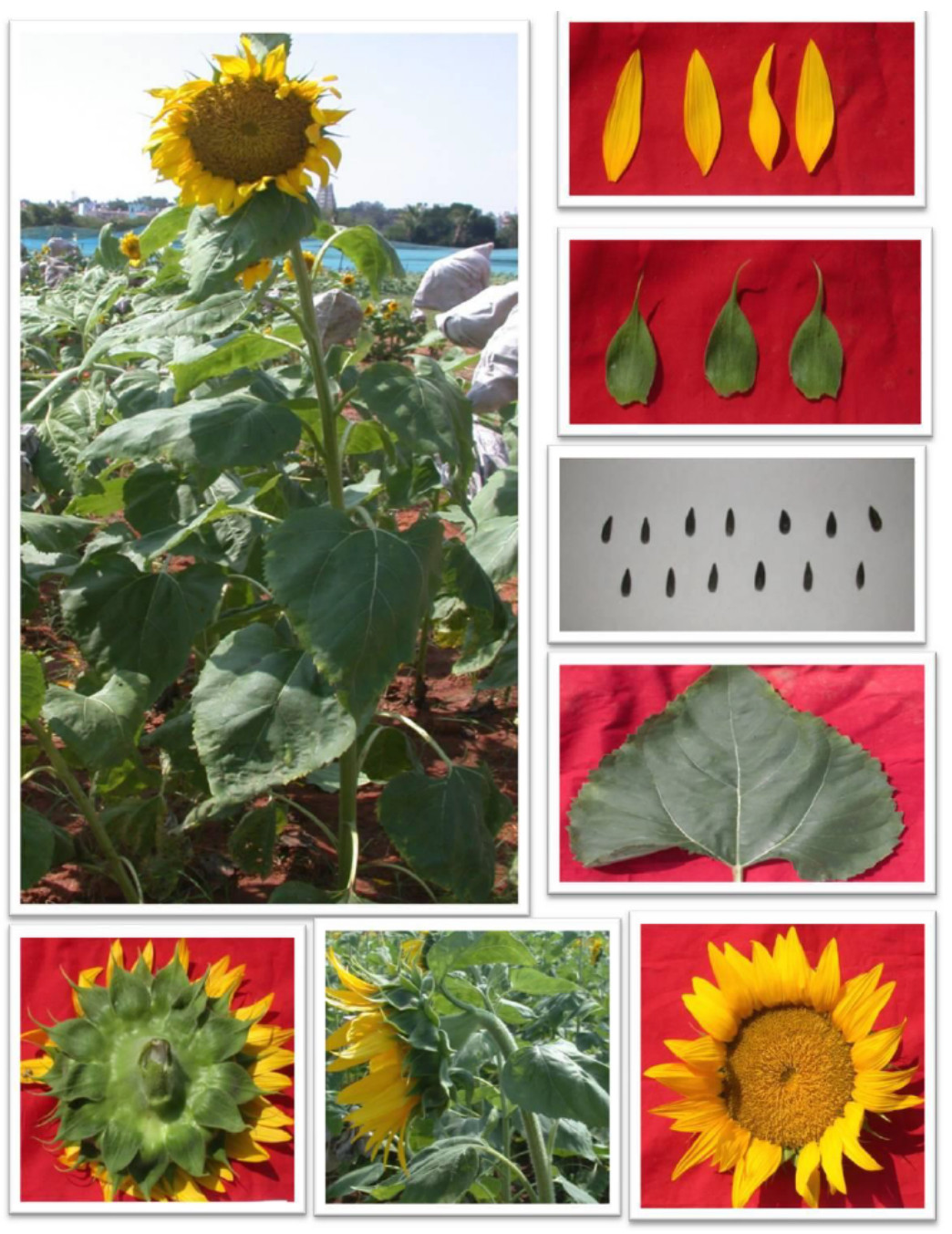

Figure 4

Diversified CMS line ARG 6-3-1-4 

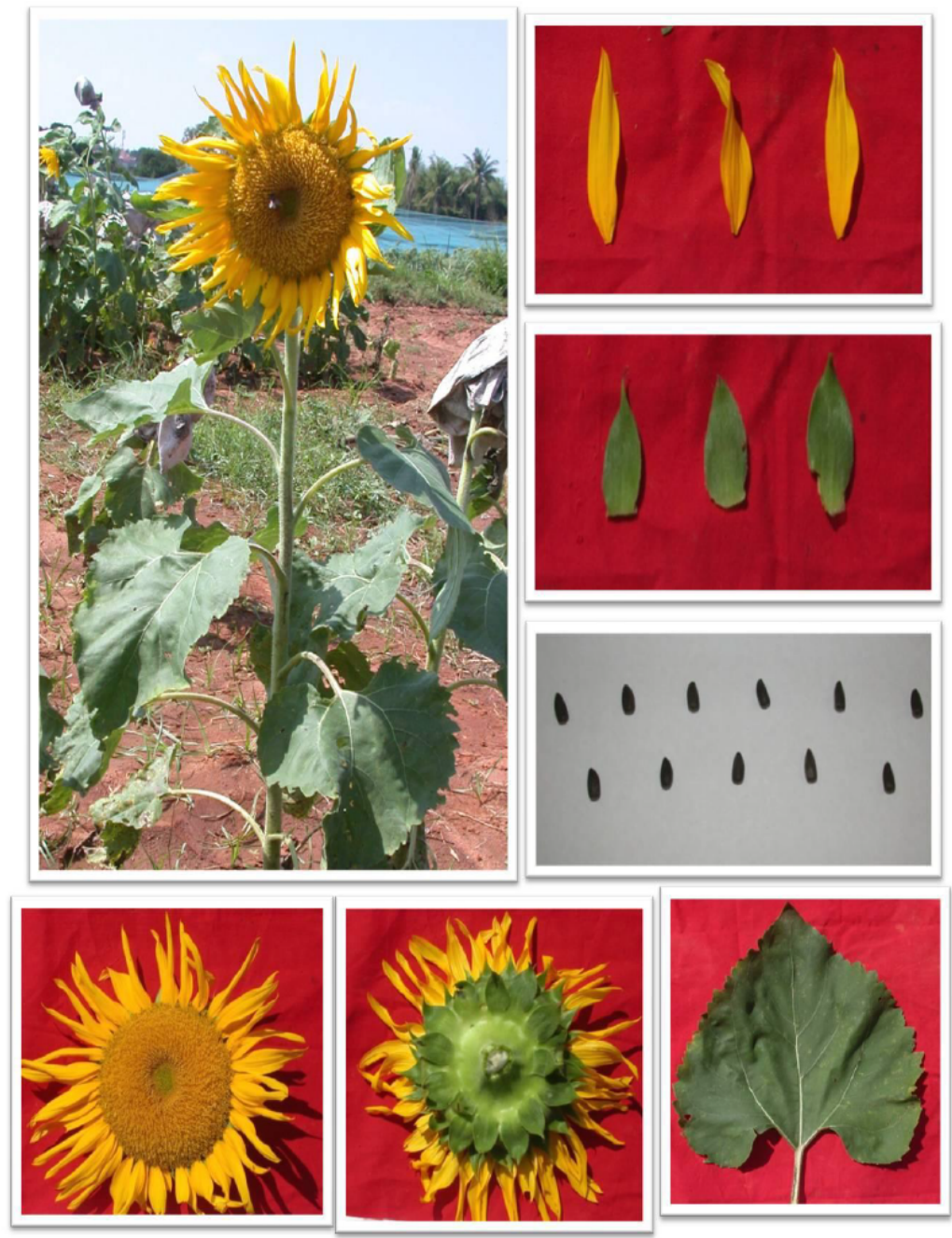

\section{Figure 5}

Diversified CMS line MUT2 8-3-2

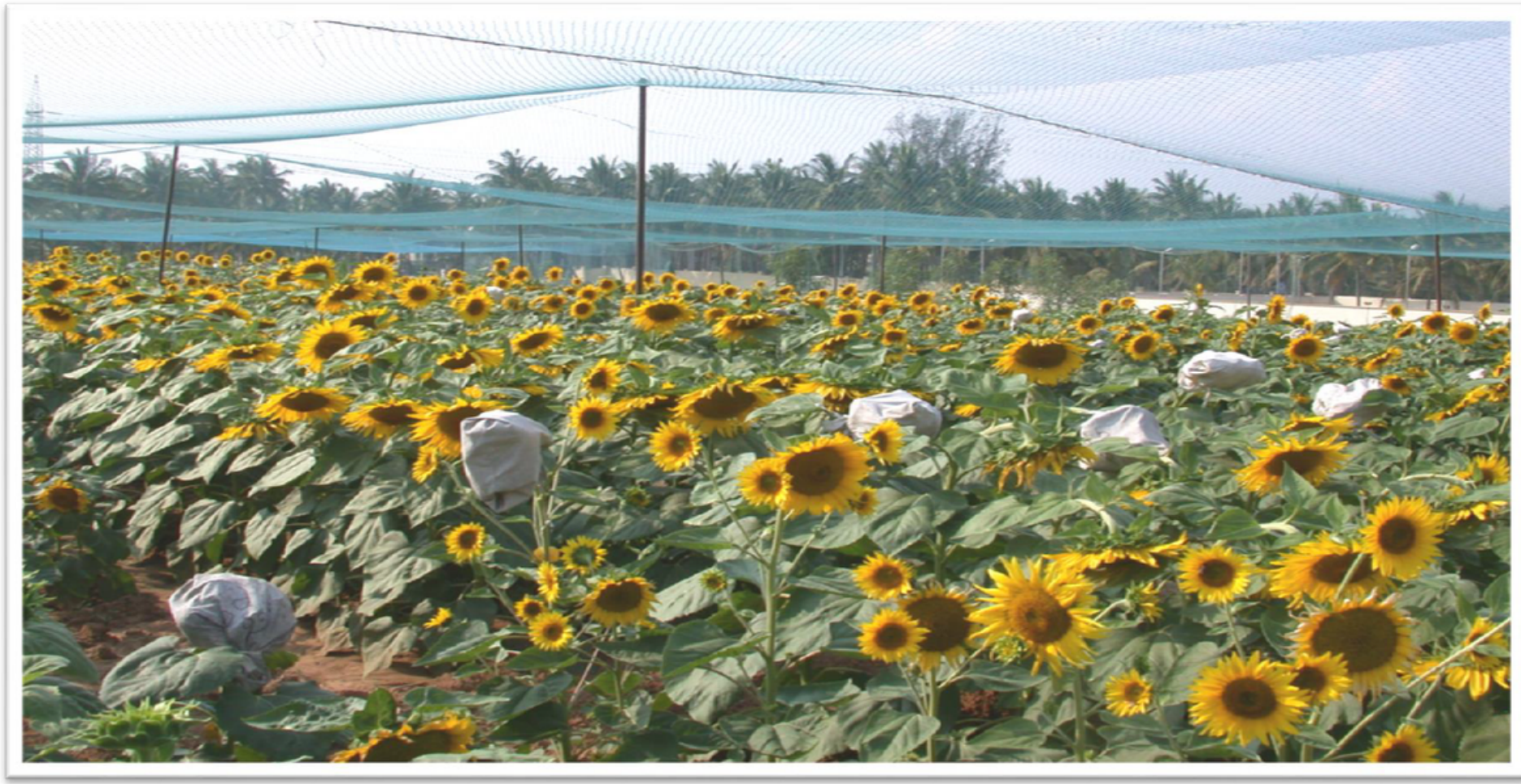


Figure 6

General View of experimental plot.

\section{Supplementary Files}

This is a list of supplementary files associated with this preprint. Click to download.

- Supplementarylnfo.docx 